\title{
Physiological and Genetic Analyses of Inbred Mouse Strains with a Type I lodothyronine 5' Deiodinase Deficiency
}

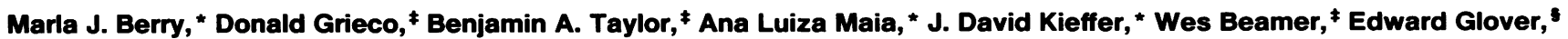 \\ Alan Poland," and P. Reed Larsen* \\ *Thyroid Division, Department of Medicine, Brigham and Women's Hospital and Harvard Medical School, Boston, Massachusetts \\ 02115; ; The Jackson Laboratory, Bar Harbor, Maine 04609; and ${ }^{\S}$ McArdle Laboratory for Cancer Research, University of Wisconsin, \\ Madison, Wisconsin 53706
}

\begin{abstract}
Inbred mouse strains differ in their capacity to deiodinate iododioxin and iodothyronines, with strains segregating into high or low activity groups. Metabolism of iododioxin occurs via the type I iodothyronine 5'deiodinase (5'DI), one of two enzymes that metabolize thyroxine $\left(T_{4}\right)$ to $3,5,3$ '-triiodothyronine $\left(T_{3}\right)$. Recombinant inbred strains derived from crosses between high and low activity strains exhibit segregation characteristic of a single allele difference. Hepatic and renal 5'DI mRNA in a high (C57BL/6J) and low ( $\mathrm{C} 3 \mathrm{H} / \mathrm{HeJ})$ strain paralleled enzyme activity and concentration, in agreement with a recent report. 5'DI-deficient mice had twofold higher serum free $T_{4}$ but normal free $T_{3}$ and thyrotropin. Brown adipose tissue 5'DII was invariant between the two strains. Southern analyses using a 5'DI probe identified a restriction fragment length variant that segregated with 5'DI activity in 33 of 35 recombinant inbred strains derived from four different pairs of high and low activity parental strains. Recombination frequencies using previously mapped loci allowed assignment of the 5'DI gene to mouse chromosome 4 and identified its approximate chromosomal position. We propose the symbol Diol to denote the mouse 5'DI gene. Conserved linkage between this segment of mouse chromosome 4 and human HSA1p predicts this location for human Dio1. (J. Clin. Invest. 1993. 92:1517-1528.) Key words: chromosomal mapping - genetics - mice - thyroxine - type I iodothyronine deiodinase
\end{abstract}

\section{Introduction}

Thyroxine $\left(\mathrm{T}_{4}\right)^{1}$ must be deiodinated to $3,5,3^{\prime}$-triiodothyronine $\left(\mathrm{T}_{3}\right)$ in order to be fully active under physiological condi-

This study was presented in part at the 66th Meeting of the American Thyroid Association, 23-26 September 1992.

Address reprint requests to Dr. Marla J. Berry, Thyroid Division, Department of Medicine, Brigham and Women's Hospital and Harvard Medical School, Boston, MA 02115.

Received for publication 17 December 1992 and in revised form 24 February 1993.

1. Abbreviations used in this paper: BAT, brown adipose tissue; $\mathrm{BrAcT}_{3}, N$-bromoacetyl-L-3,5,3'-triiodothyronine; 5'DI, type I 5' deiodinase; 5'DII, type II 5' deiodinase; $\mathrm{I}-\mathrm{CI}_{3} \mathrm{DpD}$, 2-iodo-3,7,8-trichlorodibenzo-p-dioxin; PTU, 6- $n$--propylthiouracil; RFLV, restriction fragment length variant; $R I$, recombinant inbred; $T_{3}, 3,5,3^{\prime}$-triiodothyronine; $\mathrm{T}_{4}$, thyroxine; TCDD, 2,3,7,8-tetrachlorodibenzo- $p$-dioxin; $\mathrm{TRH}$, thyrotropin-releasing hormone; TSH, thyroid-stimulating hormone (thyrotropin).

J. Clin. Invest.

(c) The American Society for Clinical Investigation, Inc.

$0021-9738 / 93 / 09 / 1517 / 12 \$ 2.00$

Volume 92, September 1993, 1517-1528 tions. Two enzymes catalyzing this reaction have been identified, the types I and II iodothyronine 5' deiodinases (5'DI and $5^{\prime}$ DII). Recently one of these, the type I enzyme, has been cloned from rat and human liver $(1,2)$. The enzyme contains selenocysteine in its catalytic site and mutation of the selenocysteine to cysteine leads to a marked decrease in the catalytic efficiency of the rat enzyme (3). Experimental selenium deficiency leads to an increase in serum $\mathrm{T}_{4}$ and a decrease in serum $\mathrm{T}_{3}$ concentration in association with a reduction in hepatic and renal $5^{\prime} \mathrm{DI}$ activity $(4,5)$. This occurs as a consequence of compensatory increases in thyroid-stimulating hormone (thyrotropin; TSH) secretion owing to the sensitivity of the hypothalamic-pituitary feedback system to circulating $T_{3}(6,7)$. Type I deiodination follows ping-pong, bisubstrate kinetics with a requirement for reduced thiol as second substrate (3). 6- $n$-propylthiouracil (PTU) is a specific inhibitor of the 5'DI and has been postulated to form a stable dead-end complex between the selenolyl iodide intermediate of the first half-reaction and the sulfhydryl group of the thiourea compound (3). In thyroidectomized rats given replacement $T_{4}, P T U$ inhibition of 5'DI causes marked hypothyroidism in the liver, which derives most of its $T_{3}$ from plasma $T_{3}(8)$.

There are only a few examples of thyroid hormone resistance in humans which could potentially be attributed to a deficiency of 5'DI $(9,10)$. Until recently, no animal models had been identified. Accordingly, it is difficult to develop an uncomplicated model of 5'DI deficiency, because both PTU administration and selenium deficiency could have other biochemical or physiological effects in the intact animal. We noted in studies of $\left[{ }^{125} \mathrm{I}\right] 2$-iodo-3,7,8-trichlorodibenzo- $p$ dioxin (iododioxin, $\left[{ }^{125} \mathrm{I}\right] \mathrm{Cl}_{3} \mathrm{DpD}$ ) metabolism, that inbred mouse strains segregated into groups exhibiting high or low hepatic iododioxin deiodinase activity. In particular, hepatic deiodination of iododioxin was $\sim 20$-fold lower in $\mathrm{C} 3 \mathrm{H} / \mathrm{HeJ}$ $(\mathrm{C} 3 \mathrm{H})$ than in $\mathrm{C} 57 \mathrm{BL} / 6 \mathrm{~J}$ (B6) mouse strains. Subsequent studies showed that the differences in enzyme activity with respect to iododioxin were also found when $\left[{ }^{125} \mathrm{I}\right] \mathrm{T}_{4}$ was used as substrate. Thus, it appeared that iododioxin was a substrate for the 5'DI and that this enzyme was expressed at different levels in these two strains. We initiated the present collaborative study $(a)$ to identify the mechanism by which 5'DI deficiency occurred, $(b)$ to explore the effects of deiodinase deficiency on serum thyroid hormones, TSH, and type II deiodinase activity, and $(c)$ to analyze the inheritance of 5'DI deficiency in recombinant inbred (RI) mouse strains by restriction fragment length variant (RFLV) analysis.

\section{Methods}

Materials. Inbred, RI, and mutant strains of mice were from either the Research or Animal Resources colonies of the Jackson Laboratory, Bar 
Harbor, ME. Mice used as source of tissues for deiodinase assays were usually $\sim 7$-wk-old males, though males and females of different ages produced similar results. [ $\left.{ }^{125} \mathrm{I}\right] \mathrm{T}_{4}, \mathrm{~T}_{3}$, and 3,3',5'-triiodothyronine (reverse $\mathrm{T}_{3}, \mathrm{rT}_{3}$ ) were from Dupont-New England Nuclear (Boston, MA). [ $\left.{ }^{125} \mathrm{I}\right] \mathrm{Cl}{ }_{3} \mathrm{DpD}(2,176 \mathrm{Ci} / \mathrm{mmol})$ was synthesized and purified as previously described (11). RNA reagents were of molecular biology grade. All other materials were of reagent grade.

Preparation of microsomes. Mice were killed by cervical dislocation, and the livers were removed and homogenized with 9 vol of MDEN buffer ( $25 \mathrm{mM}$ Mops, $1 \mathrm{mM}$ DTT, $1 \mathrm{mM}$ EDTA, and $0.02 \%$ sodium azide), and centrifuged at $10,000 \mathrm{~g}$ for $20 \mathrm{~min}$. The supernatant fraction was made $10 \mathrm{mM}$ in EDTA and centrifuged at $100,000 \mathrm{~g}$ for $1 \mathrm{~h}$. The microsomal fraction was resuspended (equivalent to $1 \mathrm{~g}$ of liver $/ \mathrm{ml}$ ) in $0.25 \mathrm{M}$ sucrose and stored at $-80^{\circ} \mathrm{C}$ until use.

$\left[{ }^{125} \mathrm{I}\right] \mathrm{Cl}_{3} \mathrm{DpD}$ deiodinase assays. The standard assay consisted of a total incubation volume of $400 \mu \mathrm{l}$ containing $9.5 \mu \mathrm{mol}$ phosphate buffer (pH 7.4), $3 \mu$ mol EDTA, $6.7 \mu$ mol DTT, $300 \mu$ g bovine serum albumin, $12.5 \mu \mathrm{g}$ liver microsomal protein, and $10 \mu \mathrm{l}$ of DMSO containing the substrate $\left(1 \mathrm{pmol}\right.$ of radiolabeled $\left[{ }^{125} \mathrm{I}\right] \mathrm{Cl}_{3} \mathrm{DpD}, \sim 4.83$ $\times 10^{-5} \mathrm{dpm}$ plus unlabeled compound to give the desired concentration). The reaction was incubated at $37^{\circ} \mathrm{C}$ in a shaker-water bath for 15 min unless otherwise indicated, terminated by the addition of $50 \mu \mathrm{l}$ $50 \%$ TCA, and placed on ice. The protein precipitate was removed by centrifugation, the supernatant was decanted, and $50 \mu \mathrm{l}$ of a solution containing $50 \% \mathrm{NH}_{4} \mathrm{OH}, 1 \mathrm{mg} \mathrm{Na} \mathrm{S}_{2} \mathrm{O}_{5}$, and $0.1 \mu \mathrm{g} \mathrm{Nal}$ was added. The solution was extracted with $2 \mathrm{ml}$ of mixed hexanes and after freezing in a dry ice-ethanol bath, the organic layer removed by decanting. Extraction with hexanes was repeated twice more. The remaining aqueous soluble radiation was quantified by gamma-scintillation spectrometry (Minaxi 5000; United Technologies-Packard, Des Plaines, IL).

Type I $5^{\prime}$ deiodination of $T_{4}$. The standard assay consisted of a total volume of $200 \mu \mathrm{l}$ containing $4.75 \mu \mathrm{mol}$ of $\mathrm{Mops}\left(\mathrm{pH} 7.3\right.$ at $37^{\circ} \mathrm{C}$ ), 0.6 $\mu$ mol EDTA, $4 \mu \mathrm{mol}$ DTT, $250 \mu \mathrm{g}$ liver microsomal protein, and $10 \mu \mathrm{l}$ of $50 \%$ methanol/aqueous phosphate buffer containing $1.6 \mathrm{pmol}\left[{ }^{125} \mathrm{I}\right]$ $\mathrm{T}_{4},(290,000 \mathrm{dpm})$ plus unlabeled $\mathrm{T}_{4}$, to give the necessary concentration as indicated. The reaction was incubated at $37^{\circ} \mathrm{C}$ in a shaker-water bath for $1 \mathrm{~h}$, and terminated by addition of $200 \mu \mathrm{l}$ of $10 \%$ TCA and 10 $\mu \mathrm{g}$ carrier $\mathrm{Nal}$. After centrifugation to remove the precipitate, the supernatant was decanted and passed over an AG 50W-X cation exchange column (BioRad Laboratories, Richmond, CA) preequilibrated and washed with $8 \mathrm{M}$ acetic acid. The radiolabel in the eluate was quantified by gamma-scintillation spectrometry.

Type I $5^{\prime}$ deiodination of $r T_{3}$. Reactions contained 4-40 $\mu \mathrm{g}$ liver or kidney microsomal protein, $2 \mathrm{nM}\left[{ }^{125} \mathrm{I}\right] \mathrm{rT}_{3}$, varying concentrations of unlabeled $\mathrm{rT}_{3}$, and 5 or $10 \mathrm{mM}$ DTT in $100 \mathrm{mM}$ potassium phosphate, $1 \mathrm{mM}$ EDTA, pH 6.9 (PE buffer), in a reaction volume of $300 \mu \mathrm{l}$. Reactions were incubated at $37^{\circ} \mathrm{C}$ for $15 \mathrm{~min}$ to $1 \mathrm{~h}$, and processed as described previously (3). All reactions were performed in duplicate.

Type II deiodinase assays. Reactions contained $2 \mathrm{nM}\left[{ }^{125} \mathrm{I}\right] \mathrm{T}_{4}$, varying concentrations of unlabeled $\mathrm{T}_{4}, 40 \mathrm{mM} \mathrm{DTT}, 1 \mathrm{mM} \mathrm{PTU}$, and $10 \mu \mathrm{g}$ brown adipose tissue (BAT) microsomal protein, $150 \mu \mathrm{g}$ brain microsomal protein, or 50-60 $\mu \mathrm{g}$ pituitary sonicate protein in PE buffer. Brain deiodinase assays also contained $1 \mu \mathrm{M} \mathrm{T}_{3}$ to saturate type III (inner ring) deiodinase activity. BAT reactions were incubated at $37^{\circ} \mathrm{C}$ for $15 \mathrm{~min}$ to $1 \mathrm{~h}$; brain and pituitary reactions were incubated for $2 \mathrm{~h}$. All reactions were performed in duplicate.

Product identification and quantitation. $\left[{ }^{125} \mathrm{I}\right] \mathrm{Cl}_{3} \mathrm{DpD},\left[{ }^{125} \mathrm{I}\right] \mathrm{T}_{4}$, the radiolabeled products of their respective deiodination, and $\mathrm{Na}^{125} \mathrm{I}$ were examined by thin-layer chromatography on LK5DF silica gel plates (Whatman Inc., Clifton, $\mathrm{NJ}$ ) with developing solvent of $N$-butanol saturated with $\mathrm{NH}_{4} \mathrm{OH}$. Iodine and $\mathrm{T}_{4}$ were visualized by staining with ferric chloride-ferricyanide and arsenite (12). All compounds were radiolabeled and visualized by autoradiography. $\left.{ }^{125} \mathrm{I}\right] \mathrm{Cl}{ }_{3} \mathrm{DpD}$ had an $R_{\mathrm{f}}$ of 0.87 , thyroxine had an $R_{\mathrm{f}}$ of 0.39 , and the radiolabeled products of incubation of both substrates cochromatographed with free ${ }^{125} \mathrm{I}^{-}$with an $R_{\mathrm{f}}$ of 0.51 . The recovery of ${ }^{125} \mathrm{I}^{-}$added to the $\mathrm{I}^{-} \mathrm{Cl} \mathrm{B}_{3} \mathrm{DpD}$ deiodination incubation (hexane extraction) was $>90 \%$, and similar near-quantitative recovery of ${ }^{125} \mathrm{I}^{-}$was observed in the $\mathrm{T}_{4}$ deiodination assay. Correction for $\left[{ }^{125} \mathrm{I}\right] \mathrm{Cl}_{3} \mathrm{DpD}$ and $\left[{ }^{125} \mathrm{I}\right] \mathrm{T}_{4}$ not separated from the product ${ }^{125} \mathrm{I}^{-}$was made by subtraction of zero time incubation blanks. Both assays yielded linear formation of product with time and with microsomal protein under the conditions employed.

Affinity labeling. Bromoacetyl $\left[{ }^{125} \mathrm{I}\right] \mathrm{T}_{3}\left(\mathrm{BrAc}\left[{ }^{125} \mathrm{I}\right] \mathrm{T}_{3}\right)$ was synthesized from bromoacetylchloride and $\left[{ }^{125} \mathrm{I}\right] \mathrm{T}_{3}$ as described previously $(2,13)$, and the iodinated product was purified by chromatography on LH-20 Sephadex. Affinity-labeling reactions contained $30 \mu \mathrm{g}$ of liver or kidney microsomal protein, $0.05 \mu \mathrm{Ci} B r A c\left[{ }^{125} \mathrm{I} \mathrm{T}_{3}\right.$ and $10 \mathrm{mM}$ DTT in PE buffer in a final volume of $50 \mu \mathrm{l}$. Labeling was at ambient temperature for $10 \mathrm{~min}$. and was terminated by addition of an equal volume of electrophoresis sample buffer containing 2.5\% SDS and 0.5 M 2-mercaptoethanol. Labeled proteins were analyzed by SDS-PAGE and autoradiography. Quantitation was performed both by densitometry (Computing Densitometer; Molecular Dynamics, Sunnyvale, CA) and by excision and counting of the $\sim 27-\mathrm{kD} 5$ DI bands, with closely agreeing results. Specific incorporation into deiodinase protein was determined by subtraction of nonspecific from total incorporation (13). Nonspecific incorporation was determined by quantitating the corresponding region from parallel gel lanes in which labeling of the $27-\mathrm{kD}$ protein was completely inhibited by addition of excess unlabeled $\mathrm{BrAcT}_{3}$

Northern blot analysis. RNA was isolated from liver and kidney by homogenizing tissues in guanidinium thiocyanate and centrifugation through cesium trifluoroacetate (Pharmacia Inc., Piscataway, NJ). Poly A+ RNA was prepared as described previously (14). RNA samples $(5 \mu \mathrm{g})$ in $50 \%$ formamide and $1.3 \%$ formaldehyde were heated at $70^{\circ} \mathrm{C}$ for $5 \mathrm{~min}$ and electrophoresed on a $1.1 \%$ agarose gel containing $20 \mathrm{mM}$ Mops ( $\mathrm{pH}$ 7.0), $5 \mathrm{mM}$ sodium acetate, $1 \mathrm{mM}$ EDTA, and $1.3 \%$ formaldehyde. RNA was blotted to GeneScreen Plus (DuPont Co., Wilmington, DE), UV cross-linked, and probed with a rat 5'DI cRNA (1), and the blot was washed at high stringency, with the final wash being in $0.1 \times \mathrm{SSC}, 0.1 \% \mathrm{SDS}$ at $65^{\circ} \mathrm{C}$. The blot was stripped by boiling and reprobed with a mouse $\beta$-actin cRNA. Quantitation of the blot was by densitometry.

Measurements of thyroid hormones and TSH. Serum $\mathrm{T}_{3}$ and $\mathrm{T}_{4}$ concentrations were quantitated by radioimmunoassays as previously described $(15,16)$. The free fractions of $T_{3}$ and $T_{4}$ were determined by equilibrium dialysis in duplicate samples, and free hormone concentrations were estimated by multiplication of the free fraction by total hormone concentration. Serum TSH was measured by radioimmunoassay using materials provided by the Hormone Distribution Program of the National Institute of Diabetes and Digestive and Kidney Diseases (NIDDK). The antigen was $\mathrm{mLH} / \mathrm{TSH}$ AFP5171.8MP. The antisera, GP-9 8/9/91 (A. F. Parlow, UCLA/Harbor, Torrance, CA), was used at a final concentration of 1:32,000. Rat TSH (NIDDKRTSH-I-9, AFP-7308C) was used as ${ }^{125}$ I-labeled antigen in the displacement assay. In sera from mice which had received $200 \mathrm{ng}$ thyrotropinreleasing hormone (TRH) intraperitoneally $30 \mathrm{~min}$ before killing to increase serum TSH, the displacement curves of the mouse standard and five serial dilutions of mouse sera (3-50 $\mu \mathrm{l}$ serum) were parallel. However, 25 and $50 \mu$ of sera from non-TRH-treated $\mathrm{C} 3 \mathrm{H}$ and B6 mice did not cause tracer displacement parallel to the standard. TSH concentrations estimated using $50 \mu \mathrm{l}$ of sera were systematically lower than those estimated using $25 \mu \mathrm{l}$. The displacement of [ $\left.{ }^{125} \mathrm{I}\right] \mathrm{rTSH}$ with both volumes was in the midportion of the standard displacement curve and was therefore not explained by a lack of sensitivity. We interpreted these results as indicating the presence of a matrix effect of mouse sera to displace [ $\left.{ }^{125} \mathrm{I}\right] \mathrm{rTSH}$. This effect was not observed in the presence of high concentrations of endogenous TSH after TRH stimulation. This was confirmed by assay of sera from mice which had received $20 \mu \mathrm{g} \mathrm{T}$ per day for $3 \mathrm{~d}$. After this treatment, serum TSH was $\sim 130 \mathrm{ng}$ "mTSH"/ml. While these results were significantly lower than the estimated TSH concentrations in euthyroid mice, they were inappropriately elevated. There was no difference between the sera of $\mathrm{B} 6$ and $\mathrm{C} 3 \mathrm{H}$ 
mice in this respect. Accordingly, we expressed all TSH concentrations based on the displacement using $25 \mu \mathrm{l}$ serum, recognizing that this is an overestimate of the authentic basal TSH concentration, though not of TRH-stimulated TSH.

Genomic DNA and Southern hybridization. Genomic DNAs were isolated from various mouse strains and Southern blots were prepared as previously described (17). Plasmid probes were labeled with $\left[{ }^{32} \mathrm{P}\right]-$ dCTP by the random hexamer labeling method (18). The resulting probes, which had a specific activity of $>3 \times 10^{8} \mathrm{cpm} / \mu \mathrm{g}$, were used in hybridization to Southern blots as described previously (19).

Isozyme typing. Mice were typed for the kidney isozyme hexose-6-phosphate dehydrogenase ( $G p d-1)$ by the Genetic Quality Control Service of the Jackson Laboratory under the supervision of Dr. Richard Fox.

Probes. The full-length rat type I deiodinase cDNA plasmid clone in Bluescript KS (1) was used to probe Southern blots. Other probes used are described in Table X (q.v.).

Statistical analysis. Estimated recombination frequencies $(r)$ between gene pairs were obtained from the analysis of RI strain data using the equation $r=\mathrm{R} /(4-6 R)$, where $R$ is the ratio of the number of RI strains with recombinant genotypes to the total number of RI strains typed (20). Confidence limits of recombination frequencies obtained from RI data were calculated as described by Silver (21). Confidence limits of recombination frequencies from testcross progeny were obtained from a table of binomial confidence intervals.

\section{Results}

Deiodination of $\left[{ }^{125} \mathrm{I}\right] C l_{3} D p D$. $\left[{ }^{125} \mathrm{ICl}_{3} \mathrm{DpD}\right.$, a radiolabeled isosteric analogue of 2,3,7,8-tetrachlorodibenzo-p-dioxin (TCDD) differing only by the substitution of an iodine atom for a chlorine atom, was synthesized to study pharmacokinetics (11). To our surprise, $\left[{ }^{125} \mathrm{I}\right] \mathrm{Cl}_{3} \mathrm{DpD}$ was rapidly eliminated from the mouse, while TCDD is known to have a whole body half-life of $2 \mathrm{wk}(22)$. This suggested that the iodine rendered the molecule subject to metabolism. Several pathways have been described for deiodination of iodinated xenobiotics (2325 ). To explore this, we incubated $\left[{ }^{125} \mathrm{I}\right] \mathrm{Cl}_{3} \mathrm{DpD}$ with glutathione, DTT, or NADPH with the whole homogenate, cytosolic, or microsomal fraction of mouse liver, and examined the unextractable, aqueous radioactivity $\left({ }^{125} \mathrm{I}^{-}\right)$formed. Liver homogenate in the presence of glutathione or DTT produced substantial deiodination, whereas modest activity was found when the liver cytosol was incubated with glutathione. The majority of the deiodinating activity was found in the hepatic microsomal fraction when incubated with DTT, but not when incubated with an NADPH-generating system.

The deiodination of $\left[{ }^{125} \mathrm{I}\right] \mathrm{Cl}_{3} \mathrm{DpD}$ by liver microsomes is dependent on DTT, increased with time of incubation and amount of microsomal protein, and has a pH optimum of 7.2. This activity was highest in microsomes from liver, appreciable in kidney, and trace activity was found in intestines (data not shown). The above characteristics suggest the enzyme involved is the type I iodothyronine deiodinase, the high capacity, low affinity deiodinase that metabolizes $T_{4}$ to $T_{3}$, and that has been shown to metabolize a number of other iodinated xenobiotics. From a study of substrate concentration versus reaction velocity, we found that $\left[{ }^{125} \mathrm{I}\right] \mathrm{Cl}_{3} \mathrm{DpD}$ deiodination by liver microsomes from B6 mice had a $V_{\max }$ of $18 \mathrm{pmol} \mathrm{I}^{-} / 12.5$ mg protein / $15 \mathrm{~min}$ and a $K_{\mathrm{m}}$ of $265 \mathrm{nM}$ at $5 \mathrm{mM} \mathrm{DTT}$. [ $\left.{ }^{125} \mathrm{I}\right]-$ $\mathrm{Cl}_{3} \mathrm{DpD}$ deiodination is competitively inhibited by $\mathrm{T}_{4}$ and $\mathrm{rT}_{3}$ (Fig. 1). Interestingly, inhibition by TCDD is noncompetitive, with a reduction in $V_{\max }$ but little effect on $K_{\mathrm{m}}$ (Fig. 2).

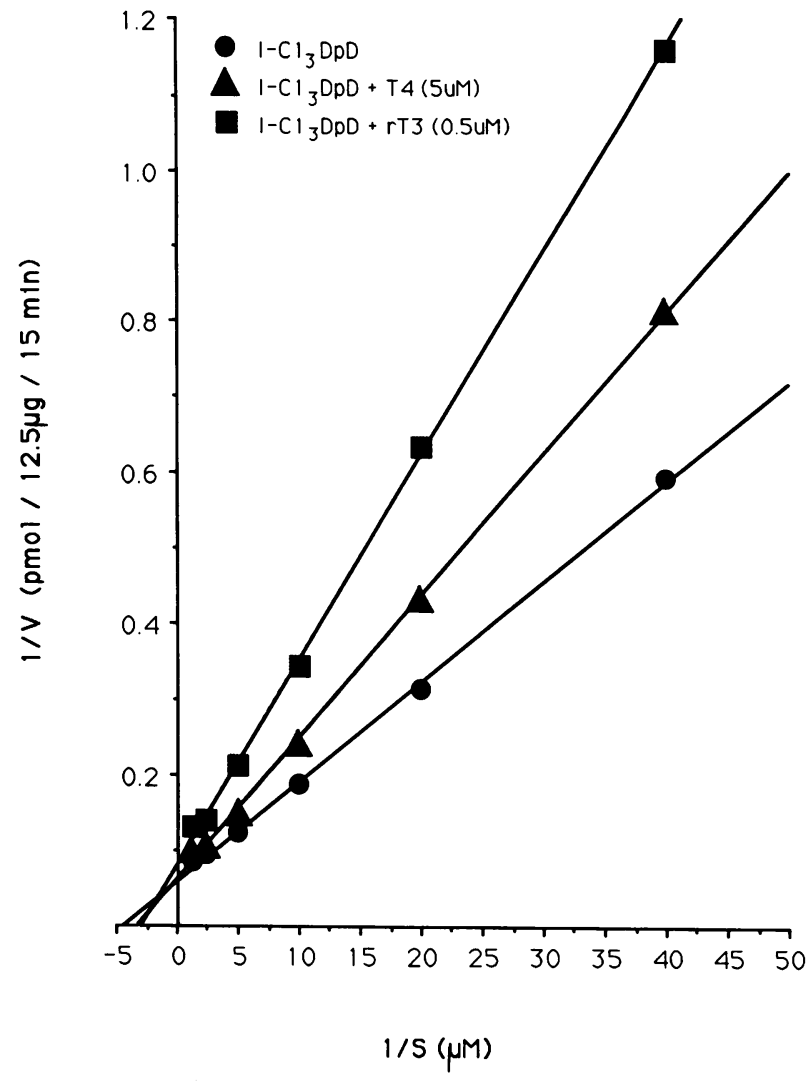

Figure 1. Kinetics of $\left[{ }^{125} \mathrm{I}\right] \mathrm{Cl}_{3} \mathrm{DpD}$ deiodination by liver microsomes and inhibition by $\mathrm{rT}_{3}$ and $\mathrm{T}_{4}$. Double reciprocal plot of rate of deiodination versus $\left[{ }^{125} \mathrm{I}\right] \mathrm{CI}_{3} \mathrm{DpD}$ concentration in the absence $(\bullet)$ or presence of T4 $(\Delta)$ or rT3 $(\bullet)$. Deiodinase activity was determined as described in Methods.

During the course of these studies, a large difference was noted in $\left[{ }^{125} \mathrm{I}\right] \mathrm{Cl}_{3} \mathrm{DpD}$ deiodinase activity in liver microsomes from $\mathrm{B} 6$ versus $\mathrm{C} 3 \mathrm{H}$ mice. Analysis of substrate versus reaction velocity indicated that $\mathrm{B} 6$ has a $V_{\max }>20$-fold greater than $\mathrm{C} 3 \mathrm{H}$, and the hybrid $\mathrm{B} 6 \mathrm{C} 3 \mathrm{~F}_{1} / \mathrm{J}$ mouse has an intermediate value. The Michaelis constants for $\left[{ }^{125} \mathrm{I}\right] \mathrm{Cl}_{3} \mathrm{DpD}$ are similar for $\mathrm{B} 6, \mathrm{C} 3 \mathrm{H}$, and $\mathrm{B} 6 \mathrm{C} 3 \mathrm{~F}_{1}$ hybrids. In light of these results, we screened a variety of inbred strains of mice for hepatic microsomal deiodination of $\left[{ }^{125} \mathrm{I}\right] \mathrm{Cl}_{3} \mathrm{DpD}$ (Table I). The strains with the lowest $V_{\max }$ are $\mathrm{C} 3 \mathrm{H}, \mathrm{CBA} / \mathrm{J}$ (not shown), and SJL/J, while B6, SWR/J, and $\mathrm{AKR} / \mathrm{J}$ have high activity. The $K_{\mathrm{m}}$ values are similar (less than twofold difference) in all strains. Comparison of deiodinase activity using $\left[{ }^{125} \mathrm{I}\right] \mathrm{Cl}_{3} \mathrm{DpD}$ versus $\left[{ }^{125} \mathrm{I}_{\mathrm{T}} \mathrm{T}_{4}\right.$ showed an excellent correlation between the two substrates for all strains of mice tested (Table II).

Segregation of iodothyronine deiodinase activity in recombinant inbred mice. The strain distribution pattern permitted us to select recombinant inbred lines developed from parental strains in which one parent had high and one low deiodinase activity. Table III shows hepatic $\mathrm{T}_{4}$ deiodinase activities in $\mathrm{B} 6$ and $\mathrm{C} 3 \mathrm{H}$ mice and in a panel of recombinant inbred strains, $\mathrm{BXH}$, derived from the cross of $\mathrm{B} 6$ and $\mathrm{C} 3 \mathrm{H}$. The recombinant strains exhibit a distinct segregation into either high or low activity categories.

Kinetic studies of 5'DI activities in B6 and C3H strains. Table IV shows results of kinetic analysis of liver and kidney 


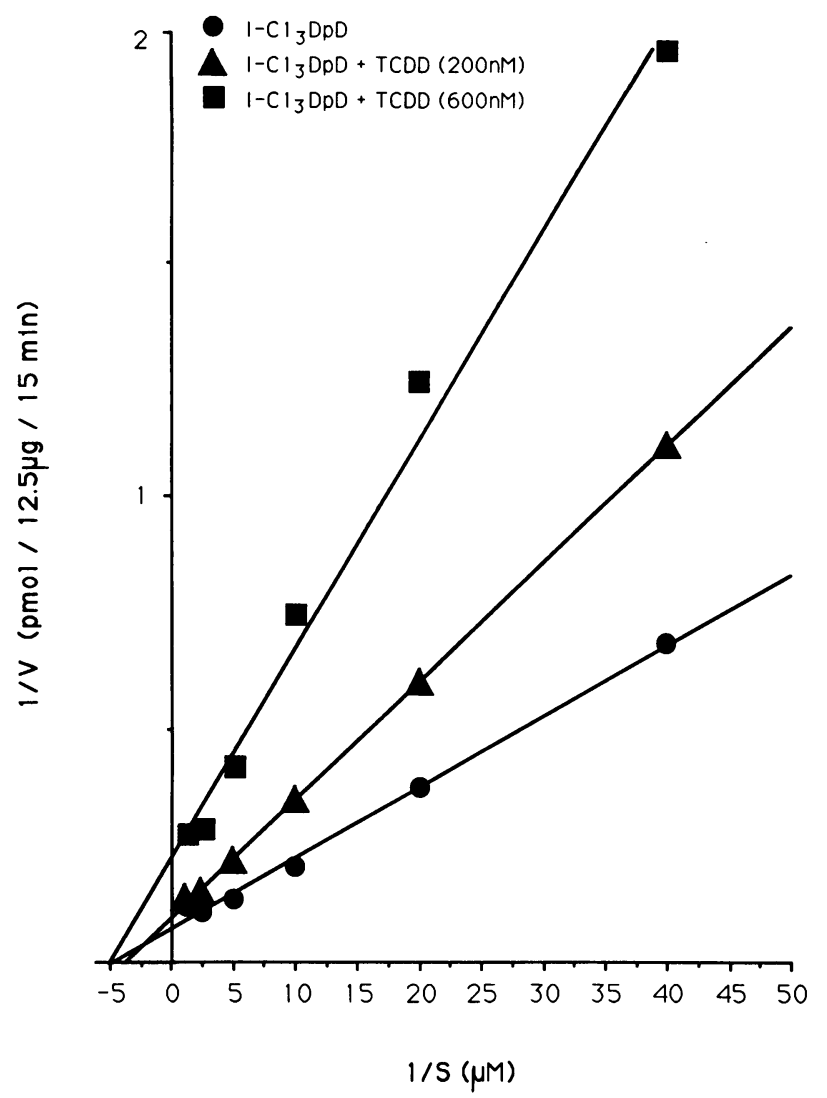

Figure 2. Kinetics of $\left[{ }^{125} \mathrm{I}\right] \mathrm{Cl}_{3} \mathrm{DpD}$ deiodination by liver microsomes and inhibition by TCDD. Double reciprocal plot of rate of deiodination versus $\left[{ }^{125} \mathrm{I}\right] \mathrm{CI}_{3} \mathrm{DpD}$ concentration in the absence $(\bullet)$ or presence of $200 \mathrm{nM}(\Delta)$ or $600 \mathrm{nM}$ TCDD ( $\bullet$ ). Deiodinase activity was determined as described in Methods.

Table I. Strain Differences in $\left[{ }^{125} \Pi\right] C l_{3} D p D$ Deiodinase Activity

\begin{tabular}{|c|c|c|}
\hline Strain & $V_{\max }$ & $K_{\mathrm{m}}$ \\
\hline & $\begin{array}{c}\text { pmol }\left[{ }^{125} I\right] C l_{3} D p D / 15 \\
\quad \text { min per } 12.5 \mu g\end{array}$ & $n M$ \\
\hline $\mathbf{A} / \mathbf{J}$ & 14.97 & 215.6 \\
\hline AKR/J & 36.91 & 254.6 \\
\hline BALB/cByJ & 8.19 & 238.2 \\
\hline $\mathrm{C} 3 \mathrm{H} / \mathrm{HeJ}$ & 0.66 & 241.5 \\
\hline C58/J & 32.43 & 278.9 \\
\hline C57BL/6J & 37.85 & 344.4 \\
\hline $\mathrm{DBA} / 2 \mathrm{~J}$ & 27.07 & 293.3 \\
\hline MA/MyJ & 8.13 & 259.4 \\
\hline NZB/BINJ & 31.20 & 324.3 \\
\hline $\mathbf{P} / \mathbf{J}$ & 33.99 & 288.9 \\
\hline $\mathbf{S J L} / \mathbf{J}$ & 3.49 & 225.4 \\
\hline $\mathrm{SM} / \mathrm{J}$ & 27.37 & 254.5 \\
\hline SWR/J & 45.05 & 310.8 \\
\hline $129 / \mathrm{J}$ & 15.19 & 209.6 \\
\hline B6C3F $1 / J$ & 19.08 & 282.3 \\
\hline
\end{tabular}

$\left[{ }^{125} \mathrm{I}_{\mathrm{CCl}} \mathrm{DpD}\right.$-deiodinase activity was determined in hepatic microsomes as described in Methods at five substrate concentrations. Duplicate determinations and a zero time blank were performed at each concentration.
Table II. Correlation of $\left[{ }^{125} \mathrm{I}\right] \mathrm{Cl} \mathrm{C}_{3} \mathrm{DpD}$ and $T_{4}$ Deiodinase Activities among Inbred Strains

\begin{tabular}{lcc}
\hline \multicolumn{1}{c}{ Strain } & $\left.{ }^{[25} \mathrm{I}\right] \mathrm{Cl}_{3}$ DpD deiodinase & {$\left[{ }^{125} \mathrm{I}\right] \mathrm{T}_{4}$ deiodinase } \\
\hline & pmol/12.5 $\mu g$ per $15 \mathrm{~min}$ & pmol/100 $\mu g$ per $2 \mathrm{~h}$ \\
$\mathrm{C} 3 \mathrm{H} / \mathrm{HeJ}$ & 0.249 & 0.539 \\
BALB/cByJ & 0.898 & 1.965 \\
MA/MyJ & 0.953 & 2.272 \\
A/J & 1.598 & 3.876 \\
DBA/2J & 2.073 & 4.888 \\
NZB/BINJ & 2.313 & 5.426 \\
P/J & 2.421 & 6.837 \\
C57BL/6J & 2.714 & 6.835 \\
SWR/J & 3.034 & 7.885 \\
AKR/J & 3.453 & 7.721 \\
\hline
\end{tabular}

Hepatic microsomes were assayed for $\left[{ }^{125} \mathrm{I}\right] \mathrm{Cl}_{3} \mathrm{DpD}$ deiodinase activity $\left(25 \mathrm{nM} \mathrm{I}-\mathrm{Cl}_{3} \mathrm{DpD}\right)$ and $\left[{ }^{125} \mathrm{I}\right] \mathrm{T}_{4}$ deiodinase activity $\left(800 \mathrm{nM} \mathrm{T}_{4}\right)$ as described in Methods. Correlation coefficient $R=0.971$.

specimens with respect to $5^{\prime}$-deiodination of the substrate, reverse $\mathrm{T}_{3} . K_{\mathrm{m}}$ values for the two strains were indistinguishable. However, the $V_{\max }$ values in C3H were 8-24-fold lower in liver and 4-5-fold lower in kidney than in the B6 strain. The lower $V_{\max }$ in the $\mathrm{C} 3 \mathrm{H}$ strain indicated either a difference in enzyme concentration or in intrinsic catalytic capacity. These two possibilities are distinguishable by quantitation of the enzyme. We therefore used affinity labeling with $\mathrm{BrAc}\left[{ }^{125} \mathrm{I}\right] \mathrm{T}_{3}(13)$ to compare the levels of the $5^{\prime} \mathrm{DI}$ enzyme in the two strains. Quantitation of label incorporated into liver and kidney microsomal 27-kD protein revealed a close agreement between covalent labeling of this protein and enzyme activity (see below). Thus, differences in enzyme concentration, rather than in catalytic capacity, account for the observed lower $V_{\max }$ in $\mathrm{C} 3 \mathrm{H}$ mice.

Table III. $T_{4}$ Deiodination in $C 57 B L / 6 J$ and $\mathrm{C} 3 \mathrm{H} / \mathrm{HeJ}$ Inbred and $\mathrm{BXH} \mathrm{RI}$ Mouse Strains

\begin{tabular}{rc}
\hline Strain & $V_{\max }$ \\
\hline & pmol $T_{4} /$ h per $100 \mu g$ protein \\
C57BL/6J & 87.0 \\
C3H/HeJ & 1.7 \\
BXH- 2 & 2.4 \\
3 & 59.2 \\
4 & 8.3 \\
6 & 68.5 \\
7 & 74.1 \\
8 & 72.6 \\
9 & 5.9 \\
10 & 15.3 \\
11 & 8.9 \\
14 & 77.0 \\
19 & 4.5 \\
\hline
\end{tabular}

Kinetic constants were derived from double-reciprocal plots. Assay conditions are as described in Methods for type I deiodination of $T_{4}$. 
Table IV. Kinetics of Type I Iodothyronine 5' Deiodinase Activity in Liver and Kidney Microsomes of C57BL/6J and C3H/HeJ Mice

\begin{tabular}{|c|c|c|c|c|}
\hline \multirow{2}{*}{ Strain } & \multicolumn{2}{|c|}{$K_{\mathrm{m}}$} & \multicolumn{2}{|c|}{$V_{\max }$} \\
\hline & Kidney & Liver & Kidney & Liver \\
\hline & \multicolumn{2}{|c|}{$\mu m$} & \multicolumn{2}{|c|}{$\underset{\text { protein }}{p m o l} r T_{3} / \min$ per $m g$} \\
\hline \multirow[t]{2}{*}{ C57BL/6J } & 0.36 & 0.36 & 235.0 & 523.6 \\
\hline & 0.82 & 0.66 & 219.5 & 581.4 \\
\hline \multirow[t]{2}{*}{$\mathrm{C} 3 \mathrm{H} / \mathrm{HeJ}$} & 0.48 & 0.32 & 60.4 & 64.1 \\
\hline & 0.62 & 0.36 & 40.7 & 25.1 \\
\hline
\end{tabular}

Kinetic constants were derived from double-reciprocal plots. Assay conditions are as described in Methods for type I deiodination of $\mathrm{rT}_{3}$. Data are the results of two independent experiments. For each experiment, tissues from three different mice were pooled to prepare the microsomes.

Studies of mRNA expression. Since differences in mRNA levels could explain the lower $5^{\prime} \mathrm{DI}$ levels in $\mathrm{C} 3 \mathrm{H}$ mice, we performed Northern analyses of 5'DI mRNA in the two strains (Fig. 3). Quantitation of deiodinase RNA normalized to a $\beta$ actin RNA revealed $\mathrm{B} 6 / \mathrm{C} 3 \mathrm{H}$ mRNA ratios of 9.3 in liver and
2.3 in kidney. The mRNAs of both strains were $\sim 2.1 \mathrm{~kb}$. Slot blot analyses of tissues from three different animals of each strain showed similar differences, with the $\mathrm{B} 6 / \mathrm{C} 3 \mathrm{H}$ ratio approximately sevenfold for liver and twofold for kidney.

A comparison of $5 \mathrm{DI} V_{\max }, \mathrm{BrAc}\left[{ }^{125} \mathrm{I}\right] \mathrm{T}_{3}$ labeling, and mRNA levels between these two strains shows that, for each strain, a close correlation exists between enzyme activity, deiodinase protein, and mRNA (Fig. 4). Thus, the 5'DI deficiency in the $\mathrm{C} 3 \mathrm{H}$ mouse can be attributed to a decrease in the quantity of mRNA for this enzyme, presumably due either to altered mRNA transcription, or stability, or both.

Serum thyroid hormone concentrations and TSH in sera of $B 6$ and $\mathrm{C} 3 \mathrm{H}$ mice. While there was no difference in the concentrations of total or free $T_{3}$ in the two mouse strains, the serum total and free $\mathrm{T}_{4}$ concentrations in the $\mathrm{C} 3 \mathrm{H}$ mice were approximately twice those of the B6 strain (Table V). The basal and TRH-stimulated TSH concentrations were also not different in the two strains of mice. As indicated in Methods, the results for the basal TSH concentrations, but not the TRHstimulated values, are confounded by displacement of [ $\left.{ }^{125} \mathrm{I}\right]-$ rTSH from the antibody by both $\mathrm{B} 6$ and $\mathrm{C} 3 \mathrm{H}$ sera. This activity is not affected by doses of exogenous $\mathrm{T}_{3}$ which suppress TSH. While the estimated basal TSH concentrations are therefore artifactually elevated, there was no difference in TSH concentrations in the $\mathrm{C} 3 \mathrm{H}$ and $\mathrm{B} 6$ inbred strains using 25,50 , or $100 \mathrm{ml}$ of serum in the radioimmunoassay.

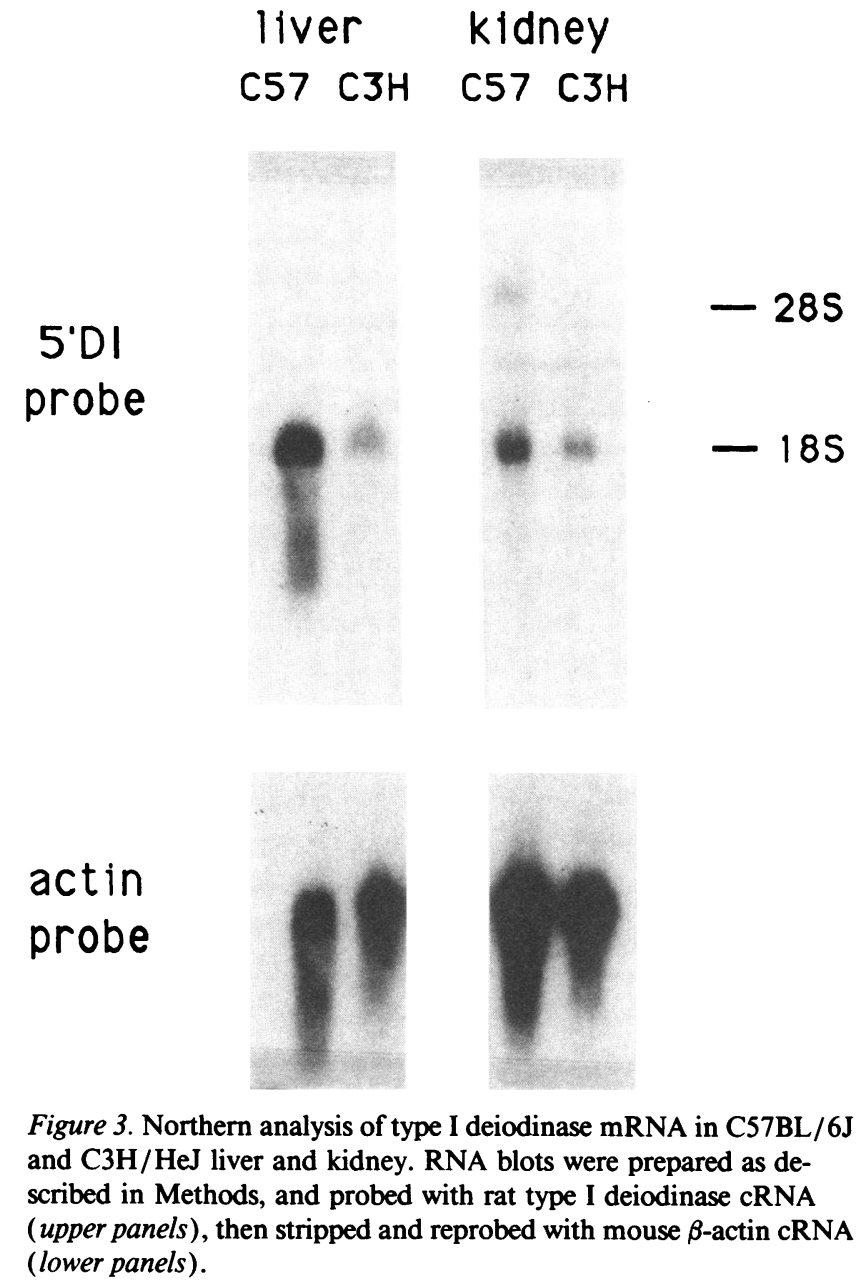

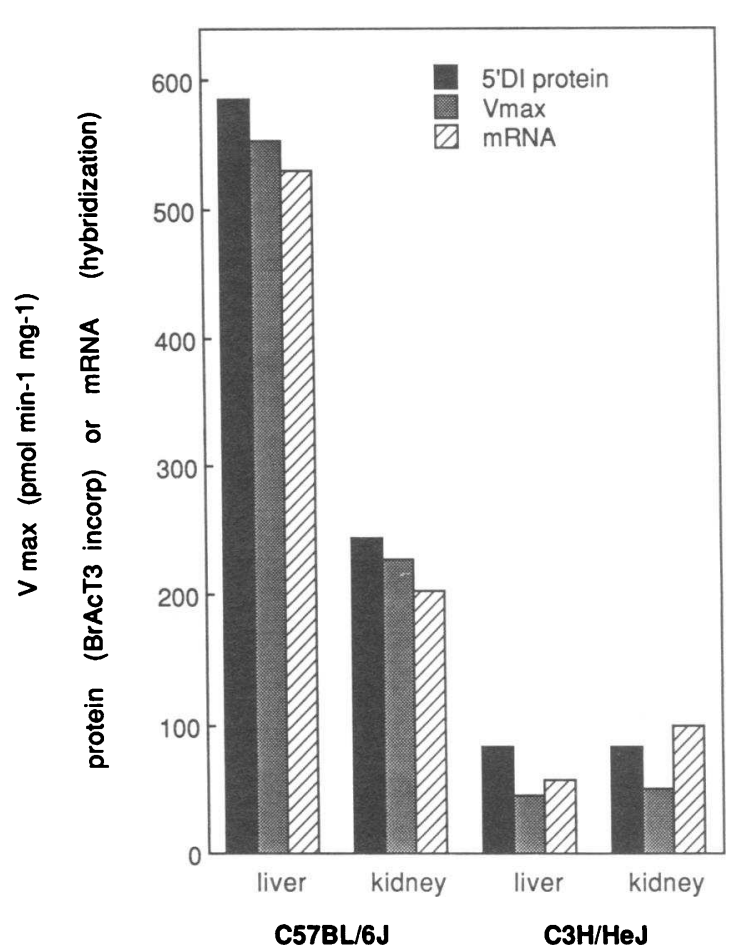

Figure 4. Quantitation of type I iodothyronine deiodinase protein, enzyme activity, and RNA in $\mathrm{C} 57 \mathrm{BL} / 6 \mathrm{~J}$ and $\mathrm{C} 3 \mathrm{H} / \mathrm{HeJ}$ liver and kidney. Relative amounts of deiodinase protein were determined by quantitation of $\left[{ }^{125} \mathrm{I}\right] \mathrm{BrAcT}_{3}$ label incorporated into $27-\mathrm{kD}$ deiodinase protein, as described in Methods, and are expressed as arbitrary densitometric units. Activity levels are the means of the values in Table IV and are expressed as $V_{\max }$ in pmol $\mathrm{min}^{-1} \mathrm{mg}^{-1}$. Type I deiodinase RNA was quantitated by densitometric scanning of the autoradiogram in Fig. 3, and is expressed in arbitrary units. 
Table V. Thyroid Hormone and TSH Concentrations in Sera from C3H/HeJ and C57BL/6J Mice

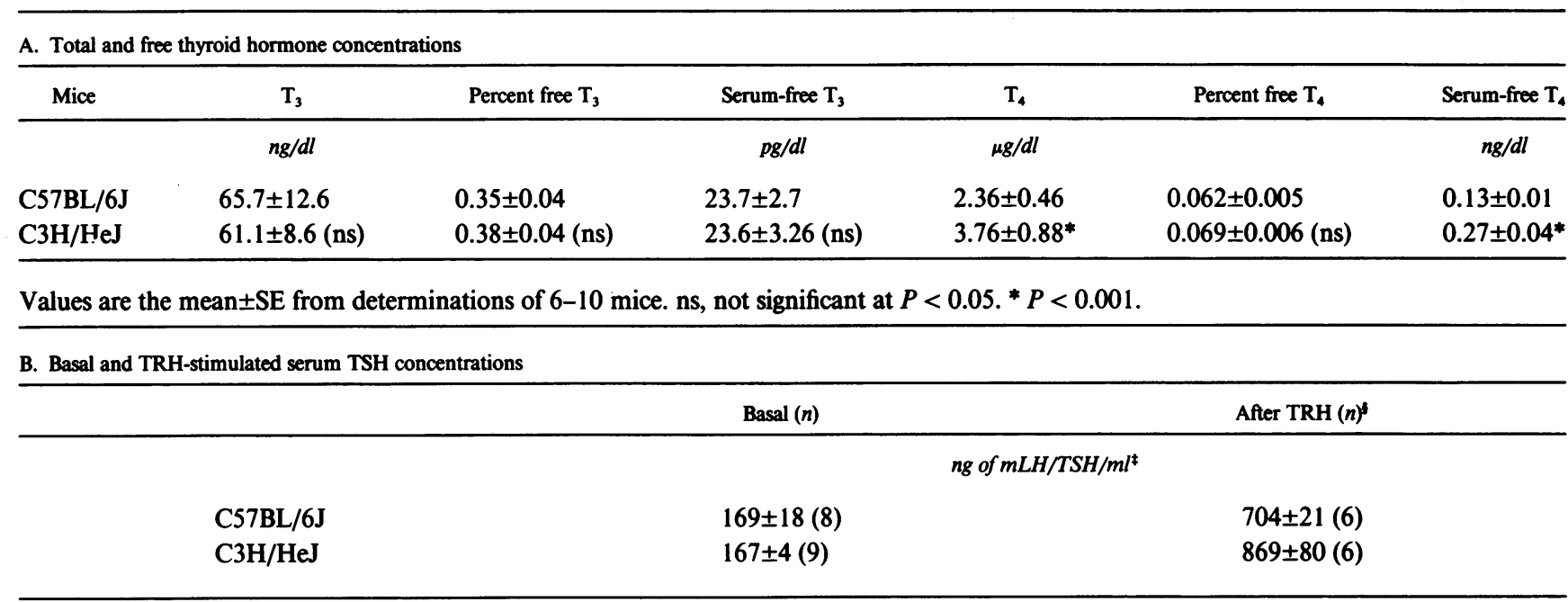

\footnotetext{
${ }^{\ddagger}$ Mean \pm SE. TSH concentrations calculated based on radioimmunoassay of $25 \mu \mathrm{l}$ of serum. ${ }^{\$}$ TRH $200 \mathrm{ng}$ intraperitoneally, 30 min before sampling.
}

Studies of Type II deiodinase. A second enzyme, the PTUresistant 5'DII, also catalyzes conversion of $\mathrm{T}_{4}$ to $\mathrm{T}_{3}$. Based on a number of biochemical studies, it is thought that this enzyme is the product of a different gene from that of the type I enzyme and furthermore, that it is not a selenoprotein $(26,27)$. We analyzed 5'DII enzyme activity in pituitary and brain of $\mathrm{C} 3 \mathrm{H}$ and $\mathrm{B} 6$ mice. The 5'DII activities in these two organs were approximately half of those in the B6 strains (Table VI). Because $5^{\prime} \mathrm{DII}$ activity is inhibited by $\mathrm{T}_{4}(28)$, this difference can

Table VI. Type II Deiodinase Activities in Pituitary,

Brain, and Brown Adipose Tissue of Euthyroid $\mathrm{C} 57 \mathrm{BL} / 6 \mathrm{~J}$ and $\mathrm{C} 3 \mathrm{H} / \mathrm{HeJ}$ Mice

\begin{tabular}{ccc}
\hline A. Pituitary and brain & \multicolumn{3}{c}{ Pituitary } & Brain \\
\hline Strain & \multicolumn{2}{c}{$f$ mol $T_{\text {s }}$ hr per mg protein } \\
& & \\
& & \\
C57BL/6J & $19.96 \pm 3.75^{*}$ & $1.542 \pm 0.156^{\ddagger}$ \\
C3H/HeJ & $10.09 \pm 1.33$ & $0.658 \pm 0.139$ \\
\hline
\end{tabular}

Reaction conditions are as described in Methods for type II deiodinase assays. Data are given as the mean $\pm \mathrm{SE}$ of six different mice of each strain. ${ }^{*}$ Significantly different from $\mathrm{C} 3 \mathrm{H}, P<0.02$. ${ }^{\ddagger}$ Significantly different from $\mathrm{C} 3 \mathrm{H}, \boldsymbol{P}<0.005$.

\begin{tabular}{lcc}
\hline \multicolumn{3}{l}{ B. Brown adipose tissue from cold exposed mice } \\
\hline Strain & $K_{\mathrm{m}}$ & $V_{\max }$ \\
\hline & $\mu M$ & $p m o l$ \\
$T_{\downarrow} /$ min per mg protein \\
C57BL/6J & 0.0051 & 1.46 \\
& 0.0029 & 0.58 \\
C3H/HeJ & 0.0098 & 1.62 \\
& 0.0032 & 0.42 \\
\hline
\end{tabular}

Kinetic constants were derived from double reciprocal plots from two experiments. For each experiment, tissues from three mice were pooled. be attributed to the twofold higher serum $\mathrm{T}_{4}$ in the $\mathrm{C} 3 \mathrm{H}$ strain. To test further the hypothesis that the 5'DII gene is not affected in the $\mathrm{C} 3 \mathrm{H}$ strain, mice were exposed to $4^{\circ} \mathrm{C}$ overnight and $5^{\prime}$ DII activity measured in brown fat (29) (Table VI). These results showed no difference in this enzyme activity between the two strains.

Deiodinase gene restriction fragment variants and genetic mapping. A panel of 15 inbred strains, including progenitors of RI strains were screened for TaqI, EcoRI, PvuII, HindIII, and SstI RFLVs. Variants were detected with TaqI, EcoRI, and PvuII, identifying four distinct haplotypes (Table VII and Fig.

Table VII. RFLVs Associated with the Diol Locus among Inbred Mouse Strains

\begin{tabular}{|c|c|c|c|c|}
\hline \multirow[b]{2}{*}{ Haplotype } & \multicolumn{3}{|c|}{$\begin{array}{l}\text { Restriction fragment } \\
\text { sizes }\end{array}$} & \multirow[b]{2}{*}{ Inbred strains } \\
\hline & TaqI & EcoRI & PvulI & \\
\hline & & $k b$ & & \\
\hline \multirow[t]{4}{*}{$a$} & 12.0 & 4.3 & 3.1 & BALB/cBy, C3H/HeJ, PL/J, SJL/J \\
\hline & 4.0 & 4.1 & 2.6 & \\
\hline & 2.9 & 3.8 & 2.3 & \\
\hline & & 3.4 & 1.7 & \\
\hline \multirow[t]{4}{*}{$b$} & 12.0 & 4.3 & 3.1 & AKR/J, B10.D2 (58N)/Sn, \\
\hline & 3.8 & 4.1 & 2.6 & C57BL/6J, C57BR/cdJ, C57L/J, \\
\hline & 2.9 & 3.8 & 2.3 & C58/J, DBA/2J, NZB/BINJ, \\
\hline & & 3.2 & 1.7 & SWR/J \\
\hline \multirow[t]{3}{*}{$c$} & 8.4 & $*$ & 4.2 & $129 / \mathrm{J}$ \\
\hline & 3.6 & & 3.1 & \\
\hline & 3.4 & & 2.6 & \\
\hline \multirow[t]{6}{*}{$d$} & 8.4 & 7.0 & 3.1 & CAST/Ei \\
\hline & 3.6 & 5.3 & 2.6 & \\
\hline & 2.6 & 4.3 & 2.3 & \\
\hline & 2.1 & 4.1 & 1.7 & \\
\hline & & 3.8 & & \\
\hline & & 3.2 & & \\
\hline
\end{tabular}

\footnotetext{
* Strain not typed.
} 
5). A subtle TaqI difference between the normal activity B6 strain versus the low activity strains BALB/cBy (BALB) and $\mathrm{C} 3 \mathrm{H}$ provided an opportunity to define the inheritance of the deiodinase structural gene relative to the deiodinase activity variant in $\mathrm{BXH}$ (from cross of $\mathrm{B} 6$ and $\mathrm{C} 3 \mathrm{H}$, Table III) and $\mathrm{CXB}$ (cross of $\mathrm{BALB} / \mathrm{cBy}$ and B6) RI strains. In order to increase the resolution of the TaqI variants, $\mathrm{B} 6$ and $\mathrm{C} 3 \mathrm{H}$ DNAs were double digested with TaqI and other restriction enzymes and analyzed by Southern blotting. Double digests with TaqI and SstI yielded a common fragment of $2.8 \mathrm{~kb}$ and a variable fragment of either $2.5 \mathrm{~kb}$ (B6) or $2.6 \mathrm{~kb}$ (BALB and $\mathrm{C} 3 \mathrm{H}$ ). This difference was employed to type the CXB and BXH RI strains (data not shown). The SWXJ (cross of SWR/J and $\mathrm{SJL} / \mathrm{J}$ ) RI strains were typed with respect to an EcoRI variant. A TaqI RFLV was used to type the NX129 (cross of NZB/ BINJ and 129/J) RI strains. All of the RI strain typings (RFLVs and activity variants described in the previous section) are summarized in Table VIII. There was complete concordance between the deiodinase RFLV and high or low deiodinase activity in 21 informative BXH and CXB RI strains. In the SWXJ RI strains, there was also concordance in all but two strains, SWXJ-11 and 12. The single SWXJ-12 mouse typed for the Diol RFLV appeared to be heterozygous. Of the two SWXJ-12 mice tested for deiodinase activity, one was clearly intermediate, while the other appeared to belong to the low activity class. In SWXJ-11, the single mouse tested for the RFLV was homozygous for the SJL/J allele, while the deiodinase activities of the two tested mice were intermediate. Since the SWXJ RI strains were not highly inbred at the time they were tested, residual heterozygosity might explain these anomalous results. We attempted to clarify this matter by testing two additional mice of both SWXJ-11 and SWXJ-12 for deiodinase activity and by typing the same mice for the deiodinase RFLV. Age and sex matched progenitor mice were analyzed simultaneously. Both strains were clearly intermediate in activity, and both were homozygous for the $\mathrm{SJL} / \mathrm{J}$ deiodinase RFLV. The correct interpretation of the SWXJ-11 and -12 strains is unclear. The fact that these two strains exhibit an intermediate deiodinase activity suggests that activity is not

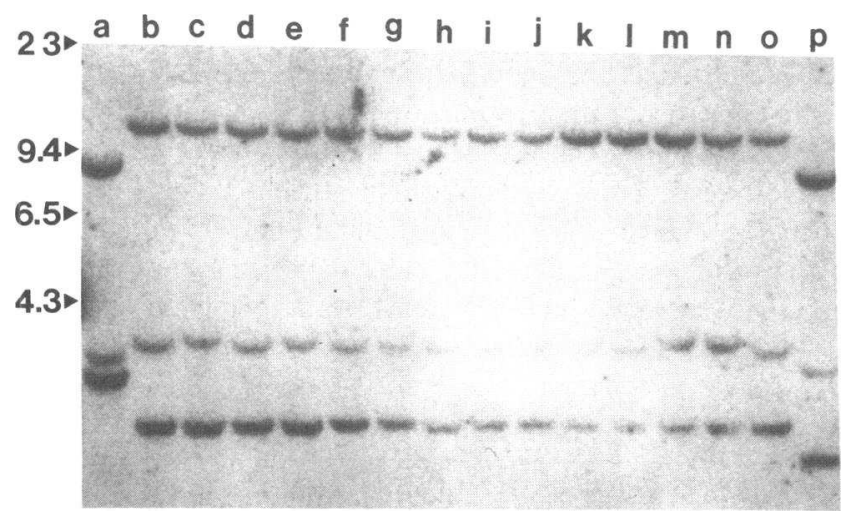

Figure 5. Southern blot showing distribution of Diol TaqI RFLVs among inbred strains. Blot hybridized with rat 5'DI cDNA probe. Lanes (mouse strains): $a, 129 / \mathrm{J} ; b, \mathrm{AKR} / \mathrm{J} ; c, \mathrm{BALB} / \mathrm{cByJ} ; d$, B10.D2(58N)Sn; $e, \mathrm{C} 3 \mathrm{H} / \mathrm{HeJ} ; f$, C57BR/cdJ male; $g$, C57BR/cdJ female; $h$, C57BL/6J; $i, \mathrm{C} 57 \mathrm{~L} / \mathrm{J} ; j$, C $58 / \mathrm{J} ; k$, DBA/2J; $l$, NZB/BINJ; $m, \mathrm{PL} / \mathrm{J} ; n, \mathrm{SJL} / \mathrm{J} ; o, \mathrm{SWR} / \mathrm{J} ; p, \mathrm{CAST} / \mathrm{Ei}$. Size markers shown at left are HindIII-digested $\lambda$ phage DNA.
Table VIII. Inheritance of Diol Alleles in RI Strains

\begin{tabular}{cll}
\hline $\begin{array}{c}\text { Diol } \\
\text { RFLV } \\
\text { haplotype* }\end{array}$ & $\begin{array}{c}\text { Deiodinase } \\
\text { phenotype }\end{array}$ & \multicolumn{1}{c}{ RI strains (progenitors) } \\
\hline$a$ & H & (C3H/HeJ), BXH-2, 4, 9, 10, 11, 19 \\
$b$ & B & (C57BL/6J), BXH-3, 6, 7, 8, 12, 14 \\
$a$ & C & (BALB/cBy), CXB-D, G, H, I, O, P \\
$b$ & B & (C57BL/6J), CXB-E, J, K, L, M, N, Q \\
$a$ & J & (SJL/J), SWXJ-3, 7, 13, 14 \\
$b$ & SW & (SWR/J), SWXJ-1, 2, 4, 5, 6, 8, 9, 10 \\
$a$ & SW/J & SWXJ-11, 12 \\
$a$ & J & (SJL/J), BXJ-1, 2 \\
$b$ & B & (C57BL/6J) \\
$b$ & n.d. & (NZB/BINJ), NX129-1, 5, 7, 10, 17, 19 \\
$c$ & n.d. & (129/J), NX129- 2, 12 \\
& & \\
\hline
\end{tabular}

* The BXH and CXB RI strains were scored for the TaqI RFLV at the Diol locus by analyzing blots of genomic DNAs digested with both TaqI and SstI. The BXH, BXJ, SWXJ, and the CXB D through K RI strains were also scored with respect to the deiodinase activity variant. The SWXJ and BXJ RI strains were scored with respect to the EcoRI RFLV. The NX129 RI strains were scored with respect to the TaqI RFLV. n.d., not determined.

strictly under the control of a single gene in this particular cross. Thus, one could postulate that there are one or more additional genes that can affect enzyme activity. Since the existence of other loci is not evident in the other strains analyzed, it is possible that there are two genes affecting activity on chromosome 4 and that one of the low activity alleles has become separated from the deiodinase RFLV in SWXJ-11 and -12 . However, the general pattern emerging from the analysis of the RI strains derived from high and low activity strains is that enzyme activity is closely associated with the deiodinase RFLV.

We propose the locus symbol Diol to denote the type I deiodinase gene of the mouse, with haplotypes $a$ through $d$ based on the RFLVs described in Table VII. It is interesting that low activity strains are found only in the $a$ haplotype. The segregation of Diol in the CXB and BXH RI strains is discordant in 2 of 19 strains with both of endogenous murine leukemia virus genomes designated Pmv-19 and Pmv-23 (30), which map near the middle of chromosome 4 (Table IX). These data suggested that Diol might map to this same region. The estimated recombination frequency (and 95\% confidence interval) between Diol and either Pmv-19 or Pmv-23 is 0.031 (0.0033-0.16). Table IX shows the strain distribution patterns for several chromosome 4 loci. The placement of Diol relative to $P m v$ - 23 and $P m v-19$ shown in Table IX is arbitrary. Furthermore, neither $P m v-19$ nor $P m v-23$ have been firmly positioned within the chromosome 4 linkage group.

In order to more precisely map Diol, we utilized an intersubspecific test cross [(CAST/Ei $\times$ MEV)F1 hybrids crossed to either BXD-32 or SWR/J] involving the MEV linkage testing stock crossed to an inbred derivative of the related Mus subspecies, Mus castaneus (19). This test cross had been typed for many DNA RFLVs and biochemical markers and has been used to map several genes $(31,32)$. A Diol TaqI RFLV was identified and scored in 90 test-cross progeny. Other chromo- 
Table IX. Inheritance of Diol and Other Chromosome 4 Loci in the CXB and BXH RI Strains

\begin{tabular}{|c|c|c|c|c|c|c|c|c|c|c|c|c|c|c|c|c|c|c|c|c|c|}
\hline \multirow[b]{2}{*}{ Locus } & \multicolumn{8}{|c|}{ CXB } & \multicolumn{13}{|c|}{ BXH } \\
\hline & $\mathrm{D}$ & $\mathrm{E}$ & G & $\mathbf{H}$ & I & $\mathbf{J}$ & K & Reference & 2 & 3 & 4 & 6 & 7 & 8 & 9 & 10 & 11 & 12 & 14 & 19 & Reference \\
\hline \multirow[t]{2}{*}{ Ifa } & $\mathrm{C}^{\mathrm{a}}$ & $\mathrm{B}^{\mathrm{a}}$ & $\mathrm{C}$ & $\mathrm{C}$ & $\mathrm{C}$ & $\mathrm{C}$ & B & $(50)$ & $\mathrm{H}^{\mathrm{a}}$ & $\mathrm{B}^{\mathrm{a}}$ & $\mathbf{H}$ & B & B & B & $\mathrm{H}$ & B & B & $\mathrm{H}$ & B & $\mathrm{H}$ & (53) \\
\hline & & & & & & & & & & & & & & & & & $\mathrm{X}$ & $\mathrm{x}$ & & & \\
\hline \multirow[t]{2}{*}{$P m v-23$} & $\mathrm{C}$ & B & $\mathrm{C}$ & $\mathrm{C}$ & $\mathrm{C}$ & $\mathrm{C}$ & B & (30) & $\mathrm{H}$ & B & $\mathrm{H}$ & B & B & B & $\mathbf{H}$ & B & $\mathrm{H}$ & B & B & $\mathrm{H}$ & (30) \\
\hline & & & & & & $\mathrm{x}$ & & & & & & & & & & $\mathrm{x}$ & & & & & \\
\hline \multirow[t]{2}{*}{ Diol } & $\mathrm{C}$ & B & C & $\mathrm{C}$ & $\mathrm{C}$ & B & B & & $\mathrm{H}$ & B & $\mathbf{H}$ & B & B & B & $\mathrm{H}$ & $\mathrm{H}$ & $\mathrm{H}$ & B & B & $\mathbf{H}$ & \\
\hline & & & & & & $\mathbf{x}$ & $\mathbf{x}$ & & & & & & & & & & & & & & \\
\hline \multirow[t]{2}{*}{ Pmv-19 } & $\mathrm{C}$ & B & $\mathrm{C}$ & $\mathrm{C}$ & $\mathrm{C}$ & $\mathrm{C}$ & $\mathrm{C}$ & (30) & $\mathrm{H}$ & B & $\mathbf{H}$ & B & B & B & $\mathrm{H}$ & $\mathbf{H}$ & $\mathbf{H}$ & B & B & $\mathrm{H}$ & (30) \\
\hline & $\mathrm{x}$ & & & & & & $\mathrm{x}$ & & & & & $\mathrm{x}$ & & & & & & & & & \\
\hline \multirow[t]{2}{*}{ Scl } & B & B & $\mathrm{C}$ & $\mathrm{C}$ & $\mathrm{C}$ & $\mathrm{C}$ & B & $(51)$ & $\mathrm{H}$ & B & $\mathrm{H}$ & $\mathrm{H}$ & B & B & $\mathrm{H}$ & $\mathrm{H}$ & $\mathrm{H}$ & B & B & $\mathbf{H}$ & $(51)$ \\
\hline & & & & & & & & & & & & & $\mathbf{x}$ & & & $\mathrm{x}$ & & & $\mathrm{x}$ & & \\
\hline$M p m v-19$ & B & B & $\mathrm{C}$ & $\mathrm{C}$ & $\mathrm{C}$ & C & B & (52) & $\mathrm{H}$ & B & $\mathbf{H}$ & $\mathbf{H}$ & $\mathrm{H}$ & B & $\mathrm{H}$ & B & $\mathbf{H}$ & B & $\mathbf{H}$ & $\mathbf{H}$ & (52) \\
\hline
\end{tabular}

The letters B, C, and $\mathrm{H}$ are used as generic symbols for alleles inherited from the C57BL/6 (By or J substrains), BALB/cBy, and C3H/HeJ progenitor strains, respectively.

some 4 RFLV loci scored in the cross and the probes used are shown in Table $\mathrm{X}$. The results shown in Table XI demonstrate unequivocal evidence for chromosome 4 linkage and indicate the following gene order (centromere to telomere) and recombination frequencies ( \pm standard errors): Tsha $0.151 \pm 0.037$

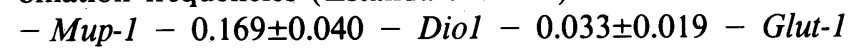
$-0.071 \pm 0.028-L c k-0.191 \pm 0.043-G p d-1$. These data confirm the assignment of Diol to chromosome 4 and places it $\sim 3$ centimorgans proximal to the glucose transporter-1 (Glut1) locus. The closest proximal marker, Mup-1, shows only loose linkage with Diol. In general, the map distances among Mtv-17, Glut-1, Lck, and Gpd-1 agree well with the consensus map.

Relationship to the obesity-diabetes syndrome mutation. Because of the profound consequences of thyroid status on activity and basal metabolic rate and their similar map positions, we considered the possibility that the recessive mutant gene diabetes (gene symbol, $d b$; for review, see reference 33 ) might be an allele at the Diol locus. This was tested by looking for a dissociation between the $d b$ mutation and its associated Diol RFLV haplotype. Since the original $d b$ mutation arose on a C57BL/KsJ, and had been transferred by successive rounds of backcrossing and intercrossing to the $\mathrm{C} 3 \mathrm{H}$.SW congenic strain background, we examined the two parental strains and the $\mathrm{C} 3 \mathrm{H} . \mathrm{SW} / \mathrm{Lt}-d b$ (N9, F8 generation) congenic strain by Southern blotting. The results showed that C57BL/KsJ was homozygous for Diol ${ }^{b}$, and both C3H.SW and C3H.SW- $d b$ were homozygous for $\mathrm{Diol}^{a}$ (data not shown). Thus, at some point in the transfer of $d b$ to its new strain background or its subsequent propagation by brother-sister mating, a crossover must have occurred and become fixed in the congenic strain. Discounting the possibility of a rare intragenic recombination, this result excludes Diol as a candidate gene for $d b$.

\section{Discussion}

The close correlation between the levels of iododioxin and iodothyronine deiodinase activities in inbred strains of mice, in conjunction with the biochemical properties, cofactor requirements, and subcellular fractionation behavior, indicated that for both classes of substrate the activity could be attributed to 5'DI. Kinetic studies demonstrate that iodothyronines are competitive inhibitors of iododioxin deiodination (Fig. 1), further evidence that both compounds are substrates for the same enzyme. The segregation of 5'DI activity from progenitor mouse strains into RI strains exhibiting either high or low hepatic 5'DI activities allowed us to investigate the mechanism, genetics, and physiological function of the mouse 5 'DI. For detailed studies of the etiology of the difference in 5'DI activity, the B6 (high) and $\mathrm{C} 3 \mathrm{H}$ (low) inbred strains were examined in detail as representatives of the two phenotypes. The data presented in Tables III and IV demonstrate that the difference in 5'DI activities with respect to $\mathrm{T}_{4}$ and $\mathrm{rT}_{3}$ can be attributed to a difference in the apparent $V_{\max }$ of the hepatic and kidney 5'DI enzyme, with no difference in $K_{\mathrm{m}}$. The results in Table III show that this difference segregates in the BXH RI strains, which have activi-

Table X. Probes and Genetic Variants Used for Mapping Deiodinase

\begin{tabular}{|c|c|c|c|c|}
\hline Locus symbol & Locus name & Clone (species) & Restriction enzyme & Reference \\
\hline Tsha & thyroid stimulating hormone, a subunit & pTSHa-1 (mouse) & BamHI & (54) \\
\hline Mup-1 & major urinary protein-1 & pLivS-1 (mouse) & PvuII & $(55)$ \\
\hline Diol & type I deiodinase & $\mathrm{G}-21$ (rat) & TaqI & (1) \\
\hline Glut-1 & glucose transporter-1 & phGT2-1 (human) & NsiI & $(56)$ \\
\hline$L c k$ & lymphocyte protein tyrosine kinase & NT18 (mouse) & $P v u \mathbf{I I}$ & $(57)$ \\
\hline
\end{tabular}


Table XI. Linkage of Diol to Genetic Markers on Chromosome 4 in CAST/Ei $\times$ MEV Test Cross

\begin{tabular}{|c|c|c|c|c|c|c|}
\hline \multicolumn{6}{|c|}{ Loci } & \multirow{2}{*}{$\begin{array}{l}\text { Number } \\
\text { of progeny }\end{array}$} \\
\hline Tsha & Mup-1 & Diol & Glut-1 & $L c k$ & $G p d-1$ & \\
\hline$C^{*}$ & $\mathrm{C}$ & $\mathrm{C}$ & $\mathrm{C}$ & C & $\mathrm{C}$ & 19 \\
\hline $\mathbf{M}^{*}$ & $\mathbf{M}$ & $\mathbf{M}$ & $\mathbf{M}$ & $\mathbf{M}$ & $\mathbf{M}$ & 17 \\
\hline $\mathrm{C}$ & $\mathbf{M}$ & $\mathbf{M}$ & $\mathbf{M}$ & $\mathbf{M}$ & $\mathbf{M}$ & 3 \\
\hline $\mathbf{M}$ & $\mathrm{C}$ & $\mathrm{C}$ & $\mathrm{C}$ & $\mathrm{C}$ & $\mathrm{C}$ & 5 \\
\hline $\mathrm{C}$ & $\mathrm{C}$ & $\mathbf{M}$ & $\mathbf{M}$ & $\mathbf{M}$ & $\mathbf{M}$ & 9 \\
\hline $\mathbf{M}$ & $\mathbf{M}$ & $\mathrm{C}$ & $\mathrm{C}$ & $\mathrm{C}$ & $\mathrm{C}$ & 6 \\
\hline $\mathrm{C}$ & $\mathrm{C}$ & $\mathrm{C}$ & $\mathbf{M}$ & $\mathbf{M}$ & $\mathbf{M}$ & 1 \\
\hline $\mathrm{C}$ & $\mathrm{C}$ & $\mathrm{C}$ & $\mathrm{C}$ & $\mathbf{M}$ & $\mathbf{M}$ & 1 \\
\hline $\mathbf{M}$ & $\mathbf{M}$ & $\mathbf{M}$ & $\mathbf{M}$ & $\mathrm{C}$ & $\mathrm{C}$ & 3 \\
\hline $\mathrm{C}$ & $\mathrm{C}$ & $\mathrm{C}$ & $\mathrm{C}$ & $\mathrm{C}$ & $\mathbf{M}$ & 5 \\
\hline $\mathbf{M}$ & $\mathbf{M}$ & $\mathbf{M}$ & $\mathbf{M}$ & $\mathbf{M}$ & $\mathrm{C}$ & 5 \\
\hline $\mathrm{C}$ & $\mathbf{M}$ & $\mathbf{M}$ & $\mathbf{M}$ & $\mathbf{M}$ & C & 1 \\
\hline $\mathbf{M}$ & $\mathrm{C}$ & $\mathrm{C}$ & $\mathrm{C}$ & $\mathrm{C}$ & $\mathbf{M}$ & 1 \\
\hline $\mathrm{C}$ & $\mathbf{M}$ & $\mathbf{M}$ & $\mathbf{M}$ & $\mathrm{C}$ & $\mathrm{C}$ & 1 \\
\hline $\mathbf{M}$ & $\mathrm{C}$ & $\mathrm{C}$ & $\mathrm{C}$ & $\mathbf{M}$ & $\mathbf{M}$ & 1 \\
\hline $\mathrm{C}$ & $\mathrm{C}$ & $\mathrm{C}$ & $\mathbf{M}$ & $\mathbf{M}$ & $\mathrm{C}$ & 1 \\
\hline $\mathrm{C}$ & $\mathrm{C}$ & $\mathrm{C}$ & $\mathrm{C}$ & - & $\mathrm{C}$ & 3 \\
\hline $\mathbf{M}$ & $\mathbf{M}$ & - & $\mathbf{M}$ & $\mathbf{M}$ & $\mathbf{M}$ & 2 \\
\hline $\mathbf{M}$ & - & $\mathbf{M}$ & $\mathbf{M}$ & $\mathbf{M}$ & $\mathrm{C}$ & 1 \\
\hline $\mathbf{M}$ & $\mathbf{M}$ & - & $\mathbf{M}$ & $\mathbf{M}$ & $\mathrm{C}$ & 1 \\
\hline $\mathrm{C}$ & $\mathrm{C}$ & - & $\mathrm{C}$ & C & $\mathbf{M}$ & 1 \\
\hline $\mathrm{C}$ & $\mathrm{C}$ & C & $\mathrm{C}$ & - & $\mathbf{M}$ & 3 \\
\hline $\mathbf{M}$ & $\mathbf{M}$ & $\mathbf{M}$ & $\mathbf{M}$ & - & $\mathrm{C}$ & 1 \\
\hline $\mathrm{C}$ & $\mathrm{C}$ & $\mathrm{C}$ & $\mathbf{M}$ & - & $\mathbf{M}$ & 1 \\
\hline $\mathrm{C}$ & $\mathbf{M}$ & - & $\mathbf{M}$ & - & $\mathbf{M}$ & 1 \\
\hline- & C & $\mathrm{C}$ & $\mathrm{C}$ & - & $\mathbf{M}$ & 1 \\
\hline $\mathrm{C}$ & $\mathbf{M}$ & $\mathbf{M}$ & $\mathbf{M}$ & - & $\mathrm{C}$ & 1 \\
\hline
\end{tabular}

Total 95

Recombination frequencies

\begin{tabular}{lccc}
\hline \multicolumn{1}{c}{ Interval } & Recombinants/total & $\begin{array}{c}\text { Recombination } \\
\text { frequency } \pm \text { SE }\end{array}$ & 95\% confidence limits \\
\hline Tsha-Mup-1 & $14 / 93$ & $0.151 \pm 0.037$ & $0.085-0.24$ \\
Mup-1-Diol & $15 / 89$ & $0.169 \pm 0.040$ & $0.098-0.26$ \\
Diol-Glut-1 & $3 / 90$ & $0.033 \pm 0.019$ & $0.0069-0.094$ \\
Glul-Lck-1 & $6 / 84$ & $0.071 \pm 0.028$ & $0.027-0.15$ \\
Lck-1-Gpd-1 & $16 / 84$ & $0.191 \pm 0.043$ & $0.11-0.29$ \\
& & & \\
\hline
\end{tabular}

* Alleles inherited from the CAST/Ei and MEV strains are denoted by the letters $C$ and $M$, respectively.

ties characteristic of either the $\mathrm{B} 6$ or $\mathrm{C} 3 \mathrm{H}$ parental strains. The difference in $5 \mathrm{DI}$ is greater in the liver (8-24-fold) than in the kidney (4-5-fold). The lower activity in $\mathrm{C} 3 \mathrm{H}$ versus $\mathrm{B} 6$ and the differences between the RI strains are due to lower content of a kinetically normal $5^{\prime}$ DI. The Northern blot studies (Fig. 3) illustrate that the difference in 5 DI activities can be explained by a difference in $5^{\prime} \mathrm{DI}$ mRNA levels. The data in Fig. 4 show the close correlation between 5 DI activity, $\mathrm{BrAc}\left[{ }^{125} \mathrm{I}^{\prime} \mathrm{T}_{3^{-}}\right.$ labeled $27-\mathrm{kD}$ protein, and 5'DI mRNA levels in liver and kidney of the two strains. These results indicate that the low activity in $\mathrm{C} 3 \mathrm{H}$ mice is not due to impaired translation or the production of an altered gene product, but to a decrease either in transcription rate or mRNA stability.

Given the clear segregation of the phenotypes in the BXH crosses, it seemed likely that this difference would be found in the $5^{\prime}$ DI gene itself. We therefore undertook genetic mapping studies to localize this defect, as a first step towards determining the specific nature of the mutation. The Diol locus has been mapped to a position $\sim 3$ centimorgans proximal to the Glut-1 locus. This provides a position of $\sim 49 \mathrm{cM}$ from the most centromeric marker in the current consensus linkage map (34), placing it close to the complement 8-beta gene (C8b). It is also apparently close to the obese-diabetes syndrome mutant gene $d b$. The latter gene has been the focus of intense interest as a model for human obesity and type II diabetes, and recently there has been a concerted effort to isolate the $d b$ gene by positional cloning. The possibility that $d b$ might be a mutant allele at the Diol locus was considered, but disproved based on the observation of a crossover event in a $d b$ congenic strain. Direct measurement of the deiodinase activity of liver homogenates of $d b / d b$ and control mice yielded indistinguishable measurements, providing further indication of the distinctness of the two loci. Although the phenotype of a mouse severely deficient in deiodinase activity can only be a matter of speculation, manifestations of thyroid insufficiency might be anticipated. In this regard, such a mouse might resemble the two known thyroid-deficient mice, hypothyroid ( $h y t)$ and congenital goiter $(\operatorname{cog})$. The syndromes presented by these mutant mice do not include marked obesity or hyperglycemia. No hypothyroid mutant has yet been identified that maps to this region of chromosome 4 for which Diol can be considered a candidate gene. If such a mutant is subsequently identified and mapped to chromosome 4, the possible association with Diol should be apparent. The position of Diol in chromosome 4 of the mouse allows the prediction that the human homolog of Diol will map to HSAlp (34). The segment of chromosome 4 homologous to HSAlp extends proximally from Jun (position 44 ) to $S k v$ (position 77) distally, and therefore represents one of the largest uninterrupted regions of conserved linkage between the two species. The placement of Diol within the chromosome 4 linkage map and the association of the $a$ haplotype with the low activity phenotype will provide a valuable reference point for further mapping in RI strains.

What are the physiological consequences of a 5-10-fold difference in 5'DI activity and what compensatory mechanisms occur in the intact animal? Data in Table $\mathrm{V}$ demonstrate that relative to the $\mathrm{B} 6$ mice, $\mathrm{C} 3 \mathrm{H}$ strains have elevated serum total and free $T_{4}$ but normal serum-free $T_{3}$ and TSH concentrations. Quantitation of free hormones is required to establish this difference, since thyroid hormone binding abnormalities have been described in certain mouse strains, e.g., $d b / d b, o b / o b$, and dystrophic animals $(16,35)$. The fact that serum-free $T_{3}$ concentrations are normal in $\mathrm{C} 3 \mathrm{H}$ animals would lead to a euthyroid state in those peripheral tissues (heart, liver, kidney, skeletal muscle) which depend predominantly on the plasma $T_{3}$ for their intracellular hormone $(36,37)$. This can account for the euthyroid phenotype of the $\mathrm{C} 3 \mathrm{H}$ strain which shows none of the manifestations of hypothyroidism found in genetically hypothyroid mice such as those with the hyt or $\operatorname{cog}$ mutations. In the iodine-sufficient rat, $65-75 \%$ of the circulating $T_{3}$ derives from a PTU-sensitive $T_{4} 5^{\prime}$-deiodination process, catalyzed by the $5^{\prime} \mathrm{DI}$ in liver and kidney $(15,37,38)$. The re- 
mainder originates from a combination of direct thyroidal $\mathrm{T}_{3}$ secretion and from PTU-insensitive $T_{4}$ to $T_{3}$ conversion (5'DII). A similar analysis has not been performed in the mouse but it seems unlikely that this situation would be very different. The normal concentration of free $\mathrm{T}_{3}$ in sera of $\mathrm{C} 3 \mathrm{H}$ mice presumably is due to the fact that, while the fractional conversion of $T_{4}$ to $T_{3}$ per day would be reduced, the higher serum-free $T_{4}$ concentration permits normal daily $T_{3}$ production. We speculate that $T_{4}$ production rates could well be normal since the higher concentrations and reduced fractional clearance could balance each other. A reduction in inner ring deiodination of $\mathrm{T}_{3}$, also a function of the 5'DI enzyme, could also contribute to maintenance of normal circulating $T_{3}$ concentrations.

An intriguing physiological question is how the hypothalamic-pituitary thyroid axis recognizes the requirement for higher serum $\mathrm{T}_{4}$ concentrations. In the rat, the degree of saturation of nuclear $T_{3}$ receptors in the pituitary correlates most accurately with the rate of TSH secretion $(6,7,39)$. There are two sources of pituitary nuclear $T_{3}$, that derived directly from the plasma and $T_{3}$ derived from intrapituitary $T_{4}$ to $T_{3}$ conversion via the type II, PTU-insensitive mechanism $(36,37)$. The 5'DII enzyme differs from 5'DI in its lower $V_{\max }$ and $K_{\mathrm{m}}$, and its very low sensitivity to inhibition by PTU or gold $(27,36)$. Recent studies have suggested that 5 DII does not contain selenocysteine $(26,27)$, and this activity is expressed in rat brown adipose tissue, which does not express 5'DI (1). The level of $5 \mathrm{DII}$ is reduced when the serum $\mathrm{T}_{4}$ concentration is increased. This regulation probably occurs post-translationally by accelerating the degradation of the 5'DII (40). Thus, in hypothyroid animals, type II deiodinase activity increases, and after $\mathrm{T}_{4}$ injections, this activity falls $(41,42)$.

It would therefore be anticipated that in $\mathrm{C} 3 \mathrm{H}$ mice, the higher serum-free $\mathrm{T}_{4}$ concentration would cause a decrease in the activity of 5'DII, and this prediction was born out by the data presented in Table VI. In both cerebral cortex and in pituitary, 5'DII activity was twofold lower in $\mathrm{C} 3 \mathrm{H}$ than in $\mathrm{B} 6$ mice. A similar phenomenon has been identified in rats made selenium deficient $(4,43)$. However, recent studies have shown that in hypothyroid animals, selenium deficiency does not reduce 5'DII activity (44). Thus, in both the $\mathrm{C} 3 \mathrm{H}$ strain and in intact selenium-deficient animals, the elevation in serum $T_{4}$ can explain the decrease in 5'DII activity in brain and pituitary. This is further confirmed by the finding of normal 5'DII activity in brown adipose tissue of $\mathrm{C} 3 \mathrm{H}$ mice (Table VI), an observation which also demonstrates that $5 \mathrm{DII}$ is not the product of the Diol gene. Since the $50 \%$ decrease in 5 'DII activity in the brain and pituitary is balanced by the elevation in serum $T_{4}$ concentration, one would predict that the $T_{3}$ contribution from this source to pituitary nuclear $T_{3}$ would be quite similar to that of the B6 animals. Therefore TSH secretion would be the same. The data in Table $\mathrm{V}$ show that TSH concentrations are not different in the two strains. Given all of these internal compensatory changes, one would expect a euthyroid state in the $\mathrm{C} 3 \mathrm{H}$ strain, which is what has been observed.

After our submission of this manuscript, Schoenmakers et al. (45) reported 5'DI activities, mRNA, and serum hormone levels in $\mathrm{C} 3 \mathrm{H}$ and $\mathrm{B} 6$ mice, initiating their studies after informal discussions with one of us (A.P.). In contrast to our findings, they observed highly variable hepatic 5'DI activities in $\mathrm{C} 3 \mathrm{H}$ mice, though the mean was $\sim 18 \%$ of that in the $\mathrm{B} 6$ strain. They also found that the levels of 5'DI mRNA and BrAc $\left[{ }^{125} \mathrm{I}\right] \mathrm{T}_{3}$-labeled 28 -kD protein were proportionately reduced in $\mathrm{C} 3 \mathrm{H}$ animals with low 5'DI activity. However, again in contrast to our results, serum total $T_{4}$ concentrations were not significantly different between $\mathrm{C} 3 \mathrm{H}$ and $\mathrm{B} 6$ strains, presumably due to the heterogeneity in 5'DI activities. We have no explanation for the disparate 5'DI results in this study, since we have not observed, in over $40 \mathrm{C} 3 \mathrm{H}$ mice, 5'DI activity or mRNA levels which overlap with the range in B6 animals. Neither 5'DII activities, free hormone concentrations, or serum TSH results were reported by Schoenmakers et al., though serum $\mathrm{rT}_{3}$ was significantly higher in the $\mathrm{C} 3 \mathrm{H}$ than in the $\mathrm{B} 6$ mice, consistent with the reduced 5 DI activity in this strain.

A putative Type I deiodinase defect has been described in one family and in one individual which may be analogous to the 5'DI differences seen in the $\mathrm{C} 3 \mathrm{H}$ and other low 5'DI strains $(9,10)$. In these individuals, serum total and free $T_{4}$ are elevated, and serum $\mathrm{T}_{3}$ and TSH are normal. These patients are also clinically euthyroid, indicating that the predominant manifestation of this defect is in the elevated serum-free $T_{4}$. The predicted location of the Diol gene on human chromosome 1 may aid in characterization of such defects as due to alterations in the 5'DI gene. Furthermore, it is conceivable that the relatively broad normal range of serum free $T_{4}$ concentrations found in humans could be explained by differences in the concentration or function of the 5'DI enzyme. Such differences would be compensated internally and be reflected only in variable concentrations of free $T_{4}$, all associated with a normal serum free $\mathrm{T}_{3}$ and TSH.

In addition to the allelic differences in type I deiodinase described herein, a number of other genetic differences between the $\mathrm{C} 3 \mathrm{H}, \mathrm{B} 6$, and BALB inbred strains have been described. $\mathrm{C} 3 \mathrm{H}$ exhibits $\sim 20-50$-fold higher susceptibility than B6 to chemically induced hepatocarcinogenesis (46). This difference appears to be due to increased responsiveness of $\mathrm{C} 3 \mathrm{H}$ liver cells to c-Ha-ras gene mutations. However, variations in tumor formation do not segregate with 5'DI, as BALB mice fall into the low tumor susceptibility category, like B6, whereas for Diol, BALB segregates with $\mathrm{C} 3 \mathrm{H}$. Differences in atherosclerotic plaque formation and plasma HDL levels in response to a high fat diet have also been studied extensively, with B6 exhibiting the highest susceptibility and lowest HDL, BALB intermediate (plaque formation and $\mathrm{HDL}$ ), and $\mathrm{C} 3 \mathrm{H}$ the most resistant, with the highest HDL. The lack of clear segregation in BALB mice suggests that the plaque formation differences are due to multigenic effects, and allelic differences correlating with atherosclerosis susceptibility have been described in apolipoprotein II on chromosome $1(47,48)$, and in a newly identified gene, Ath-2 (49). Whether or not the 5'DI polymorphism also contributes to plaque formation is unknown.

\section{Acknowledgments}

We thank Drs. William Chin, James Darnell, Graeme Bell, and Roger Perlmutter for sharing cDNA clones, and Peter Reifsnyder for determination of Tsha genotypes.

This work was supported by National Institutes of Health grants DK36256, GM18684, and CA33093, National Institute of Environ- 
mental Health Sciences grant ES 01884, National Cancer Institute Center grant 07175, and CAPES/CNPq, Brazil.

\section{References}

1. Berry, M. J., L. Banu, and P. R. Larsen. 1991. Type I iodothyronine deiodinase is a selenocysteine-containing enzyme. Nature (Lond.). 349:438-440.

2. Mandel, S. J., M. J. Berry, J. D. Kieffer, J. W. Harney, R. L. Warne, and P. R. Larsen. 1992. Cloning and in vitro expression of the human selenoprotein, type I iodothyronine deiodinase. J. Clin. Endocrinol. Metab. 75:1133-1139.

3. Berry, M. J., J. D. Kieffer, J. W. Harney, and P. R. Larsen. 1991. Selenocysteine confers the biochemical properties characteristic of the type I iodothyronine deiodinase. J. Biol. Chem. 266:14155-14158.

4. Arthur, J. R., F. Nicol, A. R. Hutchinson, and G. J. Beckett. 1990. The effects of selenium depletion and repletion on the metabolism of thyroid hormones in the rat. J. Inorg. Biochem. 39:101-108.

5. Beckett, G. J., D. A. MacDougall, F. Nicol, and J. R. Arthur. 1989. Inhibition of type I and type II iodothyronine deiodinase activity in rat liver, kidney, and brain produced by selenium deficiency. Biochem. J. 259:887-892.

6. Silva, J. E., and P. R. Larsen. 1977. Pituitary nuclear 3,5,3'-triiodothyronine and thyrotropin secretion: an explanation for the effect of thyroxine. Science (Wash. DC). 198:617-620.

7. Silva, J. E., and P. R. Larsen. 1978. Contributions of plasma triiodothyronine and local thyroxine monodeiodination to triiodothyronine to nuclear triiodothyronine receptor saturation in pituitary, liver, and kidney of hypothyroid rats. J. Clin. Invest. 61:1247-1259.

8. Silva, J. E., M. B. Gordon, F. R. Crantz, J. L. Leonard, and P. R. Larsen. 1984. Qualitative and quantitative differences in the pathways of extrathyroidal triiodothyronine generation between euthyroid and hypothyroid rats. J. Clin. Invest. 73:898-907.

9. Kleinhaus, N., J. Faber, L. Kahana, J. Schneer, and M. Scheinfeld. 1988. Euthyroid hyperthyroxinemia due to a generalized 5'-deiodinase defect. J. Clin. Endocrinol. Metab. 66:684-688.

10. Maxon, H. R., K. D. Burman, B. N. Premachandra, I. W. Chen, A Burger, P. Levy, and L. P. Georges. 1982. Familial elevations of total and free thyroxine in healthy, euthyroid subjects without detectable binding protein abnormalities. Acta Endocrinol. 100:224-230.

11. Poland, A., P. Teitelbaum, E. Glover, and A. Kende. 1989. Stimulation of in vivo hepatic uptake and in vitro hepatic binding of [ $\left.{ }^{125} \mathrm{I}\right]-2$-iodo-3,7,8-trichlorodibenzo-p-dioxin by the administration of agonists for the Ah receptor. Mol. Pharmacol. 36:121-127.

12. Dawson, R. M. C., D. C. Elliot, W. H. Elliot, and K. M. Jones. 1986. Data for Biochemical Research. 3rd edition. Clarendon Press, Oxford, UK. p. 480

13. Berry, M. J., A. L. Maia, J. D. Kieffer, J. W. Harney, and P. R. Larsen. 1992. Substitution of cysteine for selenocysteine in type I iodothyronine deiodinase reduces the catalytic efficiency but enhances its translation. Endocrinology. 131:1848-1852.

14. Berry, M. J., A. -L. Kates, and P. R. Larsen. 1990. Thyroid hormone regulates type I deiodinase messenger RNA in rat liver. Mol. Endocrinol. 4:743748.

15. Larsen, P. R., and R. D. Frumess. 1977. Comparison of the biological effects of thyroxine and triiodothyronine in the rat. Endocrinology. 100:980-988.

16. Watson, A. Y., K. Radie, M. McCarthy, P. R. Larsen, and R. A. Murphy. 1982. Thyroxine reverses deficits of nerve growth factor and epidermal growth factors in submandibular glands of mice with muscular dystrophy. Endocrinology. 110:1392-1401.

17. Taylor, B. A., and L. Rowe. 1984. Genes for serum amyloid A proteins map to chromosome 7 in the mouse. Mol. Gen. Genet. 195:491-499.

18. Feinberg, A. P., and B. Vogelstein. 1984. A technique for radiolabeling DNA restriction endonuclease fragments to high specific activity. Anal. Biochem. 137:267-268.

19. Taylor, B. A., and L. Rowe. 1989. A mouse linkage testing stock possessing multiple copies of the endogenous ecotropic murine leukemia virus genome. Genomics. 5:221-232.

20. Taylor, B. A. 1978. Recombinant inbred strains: use in gene mapping. In Origins of Inbred Mice. H. C. Morse, III, editor. Academic Press, New York. 423-438.

21. Silver, J. 1985. Confidence limits for estimates of gene linkage based on analyses of recombinant inbred strains. J. Hered. 78:436-440.

22. Gasiewicz, T. A., L. E. Geiger, G. Rucci, and R. A. Neal. 1983. Distribution, excretion, and metabolism of 2,3,7,8-tetrachlorodibenzo-p-dioxin in C57BL/6J, DBA/2J, and B6D2F / J mice. Drug Metab. Dispos. 11:397-403.

23. Wataya, Y., and D. Santi. 1975. Thymidylate synthetase catalyzed rehalogenation of 5-bromo- and 5-iodo-2'-deoxyuridylate. Biochem. Biophys. Res. Commun. 67:818-823.

24. Scott, M. T., and J. E. Sinsheimer. 1984. In vitro dehalogenation of parasubstituted aromatic halides in rat liver preparations. J. Pharm. Sci. 73:11011104.
25. Sinsheimer, J. E., T. Wang, S. Roder, and Y. Y. Shum. 1978. Mechanisms for the biodehalogenation of iodocompounds. Biochem. Biophys. Res. Commun. 83:281-286.

26. Safran, M., A. P. Farwell, and J. L. Leonard. 1991. Evidence that type II 5 deiodinase is not a selenoprotein. J. Biol. Chem. 266:13477-13480.

27. Berry, M. J., J. D. Kieffer, and P. R. Larsen. 1991. Evidence that cysteine, not selenocysteine, is in the catalytic site of type II iodothyronine deiodinase. Endocrinology. 129:550-552.

28. Leonard, J. L., M. M. Kaplan, T. J. Visser, J. E. Silva, and P. R. Larsen. 1981. Cerbral cortex responds rapidly to thyroid hormones. Science (Wash. DC). 214:571-573.

29. Silva, J. E., and P. R. Larsen. 1983. Adrenergic activation of triiodothyronine production in brown adipose tissue. Nature (Lond.). 305:712-713.

30. Frankel, W. N., J. P. Stoye, B. A. Taylor, and J. M. Coffin. 1989. Genetic identification of endogenous polytropic proviruses using recombinant inbred mice. J. Virol. 63:3810-3821.

31. Taylor, B. A., and L. Rowe. 1989. Localization of the gene encoding the $\alpha$-subunit of the acetylcholine receptor on Chromosome 2 of the mouse. Cytogenet. Cell Genet. 52:102-103.

32. Taylor, B. A., and D. Grieco. 1991. Localization of the gene encoding insulin-like growth factor I on chromosome 10 of the mouse. Cytogenet. Cell Genet. 56:57-58.

33. Coleman, D. L. 1978. Obese and diabetes: two mutant genes causing diabetes-obesity syndromes in mice. Diabetologia. 14:141-148.

34. Blank, R., J. Eppig, F. T. Fiedorek, W. N. Frankel, J. M. Friedman, K. Huppi, I. Jackson, and B. Mock. 1991. Mouse chromosome 4. Mamm. Genome. 1:S51-S78.

35. Kaplan, M. M., J. B. Young, and E. A. Shaw. 1985. Abnormal thyroid hormone binding to serum proteins in $\mathrm{ob} / \mathrm{ob}$ and $\mathrm{db} / \mathrm{db}$ genetically obese mice. Endocrinology. 117:1858-1863.

36. Larsen, P. R., J. E. Silva, and M. M. Kaplan. 1981. Relationships between circulating and intracellular thyroid hormones: physiological and clinical implications. Endocr. Rev. 2:87-102.

37. van Doorn, J., F. Roelfsema, and D. van der Heide. 1983. The effect of propylthiouracil and methimazole on the peripheral conversion of thyroxine to 3,5,3'-triiodothyronine in athyreotic thyroxine-maintained rats. Acta Endocrinol. 103:509-520.

38. Oppenheimer, J. H., H. L. Schwartz, and M. I. Surks. 1972. Propylthiouracil inhibits the conversion of L-thyroxine to L-triiodothyronine: an explanation of the antithyroxine effect of propylthiouracil and evidence supporting the concept that triiodothyronine is the active thyroid hormone. J. Clin. Invest. 51:24932497.

39. Larsen, P. R., T. E. Dick, B. P. Markovitz, M. M. Kaplan, and T. G. Gard. 1979. Inhibition of intrapituitary thyroxine to 3,5,3'-triiodothyronine conversion prevents the acute suppression of thyrotropin release in hypothyroid rats. J. Clin Invest. 64:117-128.

40. Farwell, A. P., R. M. Lynch, W. C. Okulicz, A. M. Comi, and J. L. Leonard. 1990. The actin cytoskeleton mediates the hormonally regulated translocation of type II iodothyronine 5'-deiodinase in astrocytes. J. Biol. Chem. 1265:18546-18553.

41. Silva, J. E., and J. L. Leonard. 1985. Regulation of rat cerebrocortical and adenohypophyseal type II 5'-deiodinase by thyroxine, triiodothyronine, and reverse triiodothyronine. Endocrinology. 116:1627-1635.

42. St. Germain, D. 1988. The effects and interactions of substrates, inhibitors, and the cellular thiol-disulfide balance on the regulation of type II iodothyronine 5'-deiodinase. Endocrinology. 122:1860-1868.

43. Arthur, J. R., F. Nicol, P. W. H. Rae, and G. J. Beckett. 1990. Effects of selenium deficiency on the thyroid gland and on plasma and pituitary thyrotropin and growth hormone concentrations in the rat. Clin. Chem. Enzymol. Commun. 3:209-214.

44. Chanoine, J. P., M. Safran, A. P. Farwell, P. Tranter, D. M. Ekenbarger, S. Dubord, S. Alex, J. R. Arthur, G. J. Beckett, L. E. Braverman, et al. 1992. Effects of selenium deficiency on brain type II iodothyronine 5 '-deiodinase in rats. Endocrinology. 131:479-484.

45. Schoenmakers, C. H. H., I. G. A. J. Pigmans, A. Poland, and T. J. Visser. 1993. Impairment of the selenoenzyme type I iodothyronine deiodinase in $\mathrm{C} 3 \mathrm{H} /$ He mice. Endocrinology. 132:357-361.

46. Buchmann A., R. Bauer-Hofmann, J. Mahr, N. R. Drinkwater, A. Luz, and M. Schwarz. 1991. Mutational activation of the c-HA-ras-gene in liver tumors of different rodent strains: correlation with susceptibility to hepatocarcinogenesis. Proc. Natl. Acad. Sci. USA. 88:911-915.

47. Doolittle M. H., R. C. LeBoeuf, C. H. Warden, L. M. Bee, and A. J. Lusis. 1990. A polymorphism affecting apolipoprotein A-II translational efficiency determines high density lipoprotein size and composition. J. Biol. Chem. 265:16380-16388.

48. Paigen B., D. Mitchell, P. A. Holmes, and D. Albee. 1987. Genetic analysis of strains $\mathrm{C} 57 \mathrm{BL} / 6 \mathrm{~J}$ and $\mathrm{BALB} / \mathrm{cJ}$ for Ath-1, a gene determining atherosclerosis susceptibility in mice. Biochem. Genet. 25:881-892. 
49. Paigen B., M. N. Nesbitt, D. Mitchell, D. Albee, and R. C. LeBoeuf. 1989. Ath-2, a second gene determining atherosclerosis susceptibility and high density lipoprotein levels in mice. Genetics. 122:163-168.

50. Dandoy, F., K. A. Kelley, J. DeMaeyer-Guignard, E. DeMaeyer, and P. M. Pitha. 1984. Linkage analysis of the murine interferon a locus on chromosome 4. J. Exp. Med. 160:294-302.

51. Begley, C. G., J. Visvader, A. R. Green, et al. 1991. Molecular cloning and chromosomal localization of the murine homolog of the human helix-loop-helix gene SCL. Proc. Natl. Acad. Sci. USA. 88:869-873.

52. Frankel, W. N., J. P. Stoye, B. A. Taylor, and J. M. Coffin. 1990. A linkage map of endogenous murine leukemia proviruses. Genetics. 124:221-236.

53. Fultz, M. J., and S. N. Vogel. 1989. The physical separation of $L p s$ and Ifa loci in BXH recombinant inbred mice. J. Immunol. 143:3001-3006.
54. Chin, W. W., H. M. Kronenberg, P. C. Dee, F. Maloof, and J. F. Habener. 1981. Nucleotide sequence of the mRNA encoding the pre-a-subunit of mouse thyrotropin. Proc. Natl. Acad. Sci. USA. 78:5329-5333.

55. Derman, E., K. Krauter, L. Walling, C. Weinberger, M. Ray, and J. E. Darnell. 1981. Transcriptional control in the production of liver-specific mRNAs. Cell. 23:731-739.

56. Shows, T. B., R. L. Roger, M. G. Byers, et al. 1987. Polymorphic human glucose transporter gene (GLUT) is on chromosome 1p31.3Ap35. Diabetes. 36:546-549.

57. Marth, J. D., C. Disteche, C. Pravtcheva, F. Ruddle, E. G. Krebs, and R. M. Perlmutter. 1986. Localization of a lymphocyte-specific protein tyrosine kinase gene (lck) at a site of frequent chromosomal abnormalities in human lymphomas. Proc. Natl. Acad. Sci. USA. 83:7400-7404. 